\title{
Critical hydraulic gradients for seepage- induced failure of landslide dams
}

\author{
Austin Chukwueloka-Udechukwu Okeke* and Fawu Wang
}

\begin{abstract}
Background: Landslide dams formed by rock avalanche processes usually fail by seepage erosion. This has been related to the complex sedimentological characteristics of rock avalanche dams which are mostly dominated by fragmented and pulverized materials. This paper presents a comprehensive experimental programme which evaluates the critical hydraulic and geometrical conditions for seepage-induced failure of landslide dams. The experiments were conducted in a flume tank specifically designed to monitor time-dependent transient changes in pore-water pressures within the unsaturated dam materials under steady-state seepage. Dam models of different geometries were built with either mixed or homogeneous materials. Two critical hydraulic gradients corresponding to the onset of seepage erosion initiation and collapse of the dam crest were determined for different upstream inflow rates, antecedent moisture contents, compactive efforts, grain size ranges, and dam geometries.
\end{abstract}

Results: Two major types of dam failure were identified: Type I and Type II. These were further subdivided into minor failure processes which include exfiltration, sapping, downstream toe bifurcation, and undermining of the downstream face. The critical hydraulic gradients for seepage erosion initiation varied from 0.042 to 0.147 . Experiments conducted with the mixed materials indicate that the critical hydraulic gradients for collapse of the dam crest increased with an increase in uniformity coefficient.

Conclusions: The deformation behaviour of the dams was significantly influenced by particle density, pore geometry, hydraulic conductivity, and the amount of gravel and pebbles present in the materials. The results indicate that the critical seepage velocity for failure of the dams decreased with an increase in downstream slope angle, but increased with an increase in pore geometry, dam height, dam crest width, upstream inflow rate, and antecedent moisture content.

Keywords: Exfiltration, Sapping, Hydraulic gradient, Critical seepage velocity, Wetting front propagation, Downstream slope saturation

\section{Background}

Landslide dams and other natural river blockages such as moraine dams and glacier-ice dams are formed in narrow valleys bordered by oversteepened slopes. Active geological processes in these settings such as erosion and weathering often lead to the availability of highly fractured and hydrothermally altered bedrock which constitute source materials for hillslope processes and landslide dam formation (Costa and Schuster 1988; Clague and Evans 1994; Korup et al. 2010). These potentially dangerous natural phenomena occur mostly in seismically-active regions where high orographic precipitations on rugged mountain terrain associated with frequent earthquakes and snowmelt contribute to

\footnotetext{
* Correspondence: elo_destiny@yahoo.com

Department of Geoscience, Graduate School of Science and Engineering,

Shimane University, 1060 Nishikawatsu-cho, Matsue, Shimane 690-8504, Japan
}

several geological processes that lead to mass wasting and river-damming landslides (Korup and Tweed 2007; Allen et al. 2011; Evans et al. 2011; Crosta et al. 2013). Failure of landslide dams could trigger the sudden release of stored water masses from lakes created by these damming events. This consequently produces catastrophic outburst floods and debris flows that inundate the downstream areas, causing loss of lives and infrastructural damage (O'Connor and Costa 2004; Bonnard 2011; Plaza et al. 2011). For example, the worst recorded case of landslide dam disaster occurred during the 1786 Kangding-Luding earthquake in Sichuan Province, southwest China (Dai et al. 2005). The earthquake triggered a huge landslide which dammed the Dadu River but failed ten days later and generated a catastrophic outburst flood that drowned more than 100,000 people. Similarly, Chai et al. (2000) presented 
a comprehensive account of the catastrophic failure of three landslide dams (Dahaizi, Xiaohaizi, and Deixi), triggered by the August 1933, Ms 7.5 earthquake in Diexi town, Sichuan Province, China. These landslide dams failed two months later, triggering catastrophic outburst floods that traveled more than $250 \mathrm{~km}$ downstream, and claimed about 2,423 lives. Therefore, timely evaluation of landslide dams is important for prevention of catastrophic dam failures and mitigation of disasters caused by downstream flooding of the released water masses.

Seepage erosion is one of the undermining factors affecting the stability and long-term performance of landslide dams and embankment dams. Many civil engineering and geoenvironmental studies have defined subsurface erosion processes by several terms such as piping, heave or blowout, seepage erosion, tunneling or jugging, internal erosion and sapping or spring sapping (Zasłavsky and Kassiff 1965; Jones 1981; Higgins 1982, 1984; Hutchinson 1982; Hagerty 1991; Wörman 1993; Terzaghi et al. 1996). However, a few researchers have made clear distinctions between the different processes involved in soil destabilization caused by seepage and piping (Jones 1981; Bryan and Yair 1982; Dunne 1990). The role of seepage in increasing positive pore-water pressure and causing apparent reduction of matric suction $\left(u_{a}-u_{w}\right)$ in unsaturated soils has been documented in the literature (Fredlund et al. 1978; Lam et al. 1987; Fredlund et al. 2012). Generally, landslide dams, stream banks and soil slopes are composed of unconsolidated materials which exist in unsaturated conditions. The stability of landslide dams in unsaturated conditions depends on the presence of matric suction which increases the shear strength of the soil $\tau$, as described by the equation proposed by Fredlund et al. (1978):

$$
\tau=c^{\prime}+\left(\sigma_{n}-u_{a}\right) \tan \phi^{\prime}+\left(u_{a}-u_{w}\right) \tan \phi^{b}
$$

where $c^{\prime}=$ effective cohesion of the soil, $\left(\sigma_{n}-u_{a}\right)=$ net normal stress on the failure plane, $\phi^{\prime}=$ effective friction angle with respect to the net normal stress, $\left(u_{a}-u_{w}\right)=$ matric suction, $\phi^{b}=$ angle that denotes the rate of increase in shear strength relative to matric suction. Transient changes from unsaturated to saturated conditions under steady-state seepage initiate high hydraulic gradients that accentuate subsequent reduction of apparent cohesion of the soil. This, in turn, increases seepage forces that accelerate soil mobilization, exfiltration and downstream entrainment of the eroded soil particles, as described by the equation:

$$
F_{s}=\gamma_{w} i
$$

where $F_{s}=$ seepage force per unit volume, $i=$ hydraulic gradient, $\gamma_{w}=$ unit weight of water. Detailed research on seepage erosion processes in unsaturated soils and the effects of pore-water pressure on the stability of soil slopes have been carried out by Hutchinson (1982), Iverson and Major (1986), Howard and McLane (1988), Fredlund (1995), Skempton and Brogan (1994), Crosta and Prisco (1999), Rinaldi and Casagli (1999), Dapporto et al. (2001), Lobkovsky et al. (2004), Wilson et al. (2007), Fox et al. (2007), Cancienne et al. (2008), and Pagano et al. (2010).

The concept of hydraulic criteria for assessing the likelihood of initiation of internal erosion in soils is based on the hydraulic load acting on a soil particle which must exceed the drag forces of the seeping water. This is related to the critical hydraulic gradient $i_{c}$, defined as the hydraulic gradient at which the effective stress of the soil becomes negligible. Apparently, a large number of theoretical and experimental approaches have been used to obtain critical hydraulic gradients in embankment dams, levees, dykes and other water-retaining structures. For example, Terzaghi (1943) obtained $i_{c}$ value of 1 for upward directed seepage flow as described by the following equation:

$$
i_{c}=\frac{\gamma^{\prime}}{\gamma_{w}}
$$

where $\gamma^{\prime}=$ submerged unit weight of soil, and $\gamma_{w}=$ unit weight of water. However, Skempton and Brogan (1994) observed selective erosion of fines in internally unstable cohesionless soils for upward flow conditions at critical hydraulic gradients $\left(i_{c}=0.2 \sim 0.34\right)$ lower than that obtained from Terzaghi's classical approach. Similarly, Den Adel et al. (1988) carried out tests for horizontal seepage flow and obtained critical hydraulic gradient values of 0.16 to 0.17 and 0.7 for unstable and stable soils, respectively. Ahlinhan and Achmus (2010) performed experiments with unstable soils for upward and horizontal seepage flows and obtained critical hydraulic gradient values of 0.18 to 0.23 . Ke and Takahashi (2012) obtained critical hydraulic gradients of 0.21 to 0.25 for internal erosion with binary mixtures of silica sands under one-dimensional upward seepage flow.

Whilst a lot of research has been done on critical hydraulic gradients for internal erosion, problems still exist in defining and ascribing limit values of hydraulic gradients for seepage erosion. For instance, Samani and Willardson (1981) proposed the hydraulic failure gradient $i_{f}$ defined as the hydraulic gradient at which the shear strength of a confined soil is reduced by the drag forces of the seeping water. Wan and Fell (2004) introduced $i_{\text {start }}$ and $i_{\text {boil }}$ to represent critical hydraulic gradients for the onset of internal erosion and boiling, respectively. However, the conventional one-dimensional upward seepage tests can only be used to determine the hydraulic criteria for seepage erosion in granular materials with the exclusion of other factors such as dam geometry (dam 
height, dam crest width, upstream and downstream slope angles), and rate of inflow into the upstream reservoir. Hence, elaborate evaluation of the influence of these geometrical and hydraulic factors on seepage processes in landslide dams would require carrying out flume experiments where the characteristic deformation behaviour of the dam models would allow for accurate determination of the limit values of these hydraulic parameters.

\section{Brief review of seepage erosion in soils}

Comprehensive research on seepage erosion and piping mechanisms in landslide dams (Meyer et al. 1994; Davies and McSaveney 2011; Wang et al. 2013; Okeke and Wang 2016; Wang et al. in press), levees and earth embankments (Richards and Reddy 2007), hillslopes (Ghiassian and Ghareh 2008), and stream banks (Fox and Wilson 2010), have all been completed. Variations in experimental results and opinions are strictly based on the design and method of experiment adopted, coupled with size and scale effects arising from the nature of material tested.

Seepage erosion involves the detachment and entrainment of finer soil particles through a porous medium under a hydraulic gradient caused by the seeping water (Cedergren 1977). The various processes involved in seepage erosion mechanisms in hillslopes and landslide dams have been identified. For example, sapping, as defined by Hagerty (1991) involves exfiltration over a broad area on a sloping surface such that large lenticular cavities appear as a result of concentrated seepage which removes soil particles at the exit point and increases the diameter of the evolving channel over time. Iverson and Major (1986) derived a generalized analytical method for the evaluation of seepage forces considering static liquefaction and Coulomb failure under steady uniform seepage in any direction within a hillslope. They observed that slope destabilization occurred as a result of seepage force vector, which represents a body force that corresponds to the hydraulic gradient potential. They concluded that slope stability will invariably occur when the direction of the seepage flow is such that $\lambda=90^{\circ}-\phi$, whereas the existence of a vertically upward seepage component results in Coulomb failure at similar conditions required for static liquefaction, especially when the slope angle is more or less equal to $\phi$. Howard (1988) used flume experiments and numerical simulations to evaluate sapping processes and sapping zone morphology in homogeneous, isotropic sand mixtures. His experiments identified three distinct zones at the sapping face: mass wasting zone, sapping zone and fluvial transport zone, whereas numerical simulations performed by Howard and McLane (1988) revealed that the rate of mass wasting at the sapping face is dependent on the rate of sediment transport through the fluvial transport zone.

Perzlmaier et al. (2007) presented an overview of empirically-derived critical hydraulic gradients for initiation of backward erosion in a range of soil types based on field experience in several dams and levees (Table 1). Richards and Reddy (2010) evaluated piping potential in earth structures using a modified triaxial system, referred to as the true triaxial piping test apparatus (TTPTA). This apparatus was designed for controlling confining stresses and determining critical hydraulic gradients and critical velocities required for initiation of internal erosion. Their tests found that the critical hydraulic gradient and the critical seepage velocity for internal erosion in uniform fine-grained quartz sand varied from $1.8 \times 10^{-3}$ to $2.4 \times 10^{-3}$ and $8.1 \times 10^{-3}$ to $1.1 \times 10^{-3} \mathrm{~m} / \mathrm{s}$, respectively. They concluded that the critical seepage velocity is an essential parameter for evaluation of piping potentials in non-cohesive soils. Moffat et al. (2011) used a rigid wall permeameter to study internal erosion susceptibility in widely graded cohesionless soils by imposing a unidirectional flow in either upward or downward directions such that a constant average hydraulic gradient was maintained across the specimen. They found that suffusion occurred by 'episodic migration' of the finer fraction when the imposed average hydraulic gradient was increased. Chang and Zhang (2012) determined the critical hydraulic gradients for internal erosion under complex stress states using a computer-controlled triaxial testing apparatus which allowed for independent control of hydraulic gradient and stress states. They found that under isotropic stress states, the initiation hydraulic gradient $i_{\text {start }}$ increased with an increase in effective mean stress. They further observed that under the same confining stress, the initiation gradients obtained under compression stress states were higher than those obtained under extension stress states. These findings may have cleared up some of the ambiguities associated with critical hydraulic gradients determined under one-dimensional seepage tests as noted by Fell and Fry (2013), due to the inability of the conventional method to monitor stress states of soils.

However, despite the wealth of research done so far, not much has been reported on the influence of geometrical and hydraulic conditions for seepage erosion development in landslide dams. This paper presents a comprehensive experimental programme conducted to investigate transient pore-water pressure variations and the critical hydraulic gradients for seepage-induced failure of landslide dams. A series of experiments were conducted in a flume tank modified to accurately determine the limit values of hydraulic gradients at the various stages of the dam failure process. This is in contrast to the conventional one-dimensional upward directed seepage tests performed in a modified triaxial chamber. The main objectives of this research are summarized as follows: (1) to determine the critical hydraulic gradients required for initiation $i_{i n i}$ and failure $i_{f}$ of landslide dams under different geometrical and hydraulic conditions, as well as the critical seepage velocities for erosion and debris flow mobilization; (2) to 
Table 1 Comparison of empirically-derived critical average gradients $i_{c}$ for initiation of backward erosion and piping in different soil types (Perzlmaier et al. 2007)

\begin{tabular}{llllll}
\hline & \multicolumn{2}{l}{ Soil type } & & & \\
\cline { 2 - 5 } & Gravel & Coarse sand & Medium sand & Fine sand & Source \\
\hline Chugaev & 0.25 & 0.25 & 0.15 & 0.12 & Chugaev (1962) \\
Chugaev reduced & 0.25 & 0.25 & 0.11 & 0.10 & Chugaev (1962) \\
Bligh & 0.11 & 0.083 & - & 0.067 & Bligh (1910) \\
Lane & 0.095 & 0.067 & 0.056 & 0.048 & Lane (1935) \\
Muller-Kirchenbauer, lower limit & - & 0.12 & 0.08 & 0.06 & Müller-Kirchenbauer et al. (1993) \\
Muller-Kirchenbauer, upper limit & - & 0.17 & 0.10 & 0.08 & Müller-Kirchenbauer et al. (1993) \\
Weijers \& Sellmeijer, $C_{u}=1.5$ & 0.28 & 0.18 & 0.16 & 0.09 & Weijers \& Sellmeijer (1993) \\
Weijers \& Sellmeijer, $C_{u}=3$ & 0.34 & 0.28 & 0.24 & 0.14 & Weijers \& Sellmeijer (1993) \\
\hline
\end{tabular}

investigate the effects of pore-water pressure during seepage processes and its role in initiating seepage erosion and dam failure; and (3) to identify the various failure mechanisms of landslide dams under steady-state seepage conditions.

\section{Experimental Methods Testing facility}

The experiments were conducted in a rectangular flume tank $2 \mathrm{~m}$ long, $0.45 \mathrm{~m}$ wide and $0.45 \mathrm{~m}$ high. The flume tank was made of $5 \mathrm{~mm}$-thick acrylic sheets (plexiglass) of high transparency which enables visual observation of wetting front propagation, deformation and failure mechanism of the dam models. The flume was tilted to make a bed slope of $\psi=5^{\circ}$. The downstream end of the flume was equipped with two $4 \mathrm{~cm}$-diameter holes for outflow of fluidized sediments. The water entering the upstream reservoir was provided by a rubber hose attached to a water tap while discharge into the upstream reservoir was controlled by a flowmeter connected to the drainage hose. The generation and dissipation of pore-water pressures during the experiments were monitored with three pore-water pressure sensors, hereafter referred to as $p 1, p 2$, and $p 3$, with rated capacity of $50 \mathrm{kPa}$ each (Fig. 1a). The sensors were fixed underneath the center of the flume bed through three $10 \mathrm{~mm}$-diameter holes drilled on a horizontal line at the center of the flume bed. The sensors were separated by horizontal distances of $0.1 \mathrm{~m}$ and $0.103 \mathrm{~m}$, respectively. Each of the pore-water pressure sensors was equipped with an L-shaped manometer attached to the outer wall of the flume to ensure an equal balance between the fluid pressure and atmospheric pressure. Transient variation in upstream reservoir level was monitored with a water level probe positioned near the toe of the upstream slope. Deformations and settlements caused by seepage and pore-water pressure buildup were monitored with two $0.1 \mathrm{~m}$-range CMOS multi-function analog laser displacement sensors attached to a wooden overboard (Fig. 1b). The two sensors, hereafter referred to as $H_{d 1}$ and $H_{d 2}$, were separated by a distance of $0.04 \mathrm{~m}$.

\section{Soil characteristics}

A series of experiments were conducted using different soils and testing conditions. Table 2 shows a summary of all the experiments conducted under different testing conditions while the results of the critical pore-water pressures and critical seepage velocities obtained from the tests are summarized in Table 3. Uniform commercial silica sand no. 8 was used to build the dam models, except in Exp 1 to 3 where the dam models were composed of different proportions of silica sand nos. 5 and 8, including industrial pebbles and gravel, hereafter referred to as sandfill dam $(S D)$, gravelly dam I $(G V-I)$, and gravelly dam II (GV-II),

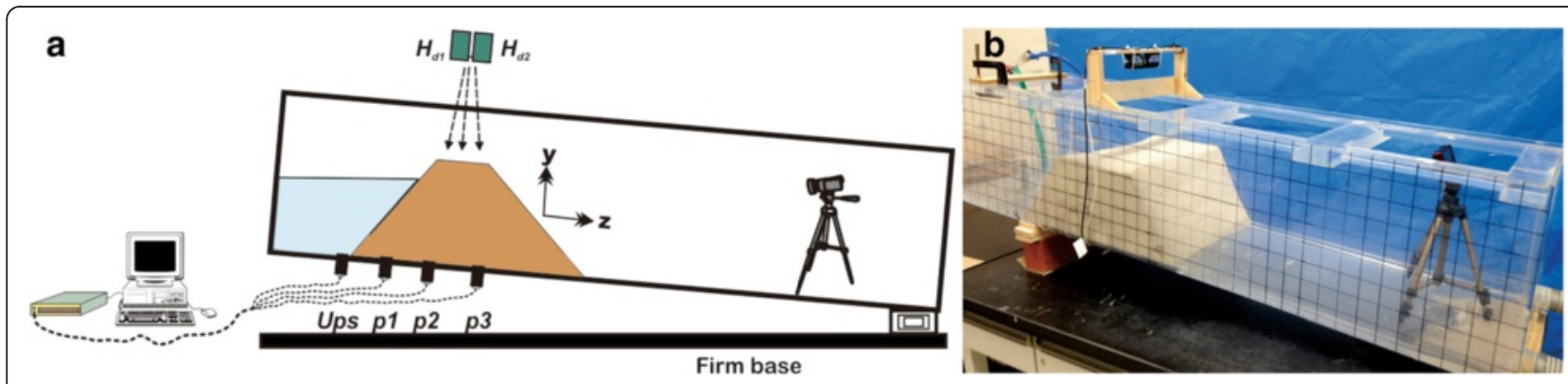

Fig. 1 a Experimental setup. $H_{d}$ Laser displacement sensors; Ups Upstream water level probe; $p 1, p 2$, and $p 3$ Pore-water pressure sensors. b Side view of the flume tank before the commencement of an experiment 
Table 2 Summary of all the experiments at different testing conditions

\begin{tabular}{|c|c|c|c|c|c|c|c|c|c|c|c|c|c|}
\hline \multirow[t]{2}{*}{ Test specification } & \multirow{2}{*}{$\begin{array}{l}\text { Test } \\
\text { no. }\end{array}$} & \multicolumn{4}{|c|}{ Dam geometry } & \multirow[t]{2}{*}{$Q_{\text {in }}\left(\mathrm{m}^{3} / \mathrm{s}\right)$} & \multirow{2}{*}{$\begin{array}{l}\rho_{d r y} \\
\left(\mathrm{Mg} / \mathrm{m}^{3}\right)\end{array}$} & \multirow[t]{2}{*}{$e_{0}$} & \multirow[t]{2}{*}{$i_{i n i-1}$} & \multirow[t]{2}{*}{$i_{\text {ini-2 }}$} & \multirow[t]{2}{*}{$i_{f 1}$} & \multirow[t]{2}{*}{$i_{f 2}$} & \multirow{2}{*}{$\begin{array}{l}T_{b} \\
(\mathrm{~s})\end{array}$} \\
\hline & & $H_{d}(\mathrm{~m})$ & $D_{c r w}(m)$ & $a(\mathrm{deg})$ & $\beta$ (deg) & & & & & & & & \\
\hline \multirow[t]{3}{*}{ Dam composition } & $\operatorname{Exp} 1$ & 0.25 & 0.1 & 40 & 55 & $2 \times 10^{-4}$ & 1.10 & 1.41 & 0.119 & 0.101 & 0.77 & 0.61 & 340 \\
\hline & $\operatorname{Exp} 2$ & 0.25 & 0.1 & 40 & 55 & $2 \times 10^{-4}$ & 1.56 & 0.71 & 0.092 & 0.123 & 1.82 & 0.87 & 920 \\
\hline & Exp 3 & 0.25 & 0.1 & 40 & 55 & $2 \times 10^{-4}$ & 1.44 & 0.84 & 0.053 & 0.101 & 1.48 & 1.20 & 1360 \\
\hline \multirow{4}{*}{$\begin{array}{l}\text { Rate of inflow into the upstream } \\
\text { reservoir (filling rate) }\end{array}$} & Exp 4 & 0.25 & 0.1 & 35 & 50 & $1.67 \times 10^{-5}$ & 1.07 & 1.48 & 0.097 & 0.099 & 1.38 & 0.90 & 1750 \\
\hline & $\operatorname{Exp} 5$ & 0.25 & 0.1 & 35 & 50 & $5 \times 10^{-5}$ & 1.07 & 1.48 & 0.122 & 0.089 & 1.50 & 0.94 & 1300 \\
\hline & Exp 6 & 0.25 & 0.1 & 35 & 50 & $1 \times 10^{-4}$ & 1.07 & 1.48 & 0.115 & 0.067 & 1.48 & 0.99 & 1100 \\
\hline & $\operatorname{Exp} 7$ & 0.25 & 0.1 & 35 & 50 & $1.67 \times 10^{-4}$ & 1.07 & 1.48 & 0.103 & 0.08 & 1.36 & 1.32 & 890 \\
\hline \multirow{4}{*}{$\begin{array}{l}\text { Antecedent moisture content at } \\
\text { low compactive effort }\left(e_{o}=1.76\right)\end{array}$} & Exp 8 & 0.25 & 0.1 & 35 & 55 & $1.5 \times 10^{-4}$ & 0.96 & 1.76 & 0.118 & 0.08 & 1.70 & 0.92 & 800 \\
\hline & $\operatorname{Exp} 9$ & 0.25 & 0.1 & 35 & 55 & $1.5 \times 10^{-4}$ & 0.96 & 1.76 & 0.094 & 0.084 & 1.59 & 0.94 & 720 \\
\hline & Exp 10 & 0.25 & 0.1 & 35 & 55 & $1.5 \times 10^{-4}$ & 0.96 & 1.76 & 0.104 & 0.085 & 1.57 & 1.00 & 680 \\
\hline & Exp 11 & 0.25 & 0.1 & 35 & 55 & $1.5 \times 10^{-4}$ & 0.96 & 1.76 & 0.103 & 0.053 & 1.40 & 1.07 & 620 \\
\hline \multirow{4}{*}{$\begin{array}{l}\text { Antecedent moisture content at } \\
\text { high compactive effort }\left(e_{o}=1.21\right)\end{array}$} & Exp 12 & 0.25 & 0.1 & 35 & 55 & $1.3 \times 10^{-4}$ & 1.20 & 1.21 & 0.087 & 0.133 & 1.17 & 0.64 & 980 \\
\hline & Exp 13 & 0.25 & 0.1 & 35 & 55 & $1.3 \times 10^{-4}$ & 1.20 & 1.21 & 0.147 & 0.123 & 1.22 & 0.70 & 840 \\
\hline & Exp 14 & 0.25 & 0.1 & 35 & 55 & $1.3 \times 10^{-4}$ & 1.20 & 1.21 & 0.093 & 0.125 & 1.28 & 0.95 & 760 \\
\hline & Exp 15 & 0.25 & 0.1 & 35 & 55 & $1.3 \times 10^{-4}$ & 1.20 & 1.21 & 0.042 & 0.103 & 1.30 & 1.00 & 740 \\
\hline \multirow[t]{4}{*}{ Downstream slope angle } & Exp 16 & 0.25 & 0.15 & 35 & 30 & $1 \times 10^{-4}$ & 1.01 & 1.62 & 0.123 & 0.091 & 1.01 & 0.73 & 2300 \\
\hline & Exp 17 & 0.25 & 0.15 & 35 & 40 & $1 \times 10^{-4}$ & 1.01 & 1.58 & 0.091 & 0.099 & 1.03 & 0.74 & 1500 \\
\hline & Exp 18 & 0.25 & 0.15 & 35 & 50 & $1 \times 10^{-4}$ & 1.01 & 1.52 & 0.128 & 0.053 & 1.39 & 0.61 & 1150 \\
\hline & Exp 19 & 0.25 & 0.15 & 35 & 60 & $1 \times 10^{-4}$ & 1.01 & 1.48 & 0.099 & 0.092 & 1.37 & 0.58 & 900 \\
\hline \multirow[t]{4}{*}{ Dam height } & $\operatorname{Exp} 20$ & 0.15 & 0.15 & 40 & 50 & $1.2 \times 10^{-4}$ & 1.10 & 1.41 & 0.111 & 0.063 & 1.17 & 0.55 & 890 \\
\hline & Exp 21 & 0.20 & 0.15 & 40 & 50 & $1.2 \times 10^{-4}$ & 1.10 & 1.41 & 0.045 & 0.133 & 1.30 & 0.79 & 1020 \\
\hline & $\operatorname{Exp} 22$ & 0.25 & 0.15 & 40 & 50 & $1.2 \times 10^{-4}$ & 1.10 & 1.41 & 0.103 & 0.043 & 1.33 & 0.82 & 1080 \\
\hline & Exp 23 & 0.30 & 0.15 & 40 & 50 & $1.2 \times 10^{-4}$ & 1.10 & 1.41 & 0.116 & 0.071 & 1.35 & 0.85 & 1280 \\
\hline \multirow[t]{2}{*}{ Dam crest width } & Exp 24 & 0.25 & 0.20 & 35 & 55 & $1.67 \times 10^{-4}$ & 1.14 & 1.32 & 0.086 & 0.083 & 1.60 & 0.86 & 1380 \\
\hline & $\operatorname{Exp} 25$ & 0.25 & 0.25 & 35 & 55 & $1.67 \times 10^{-4}$ & 1.14 & 1.32 & 0.118 & 0.081 & 1.78 & 0.89 & 2600 \\
\hline
\end{tabular}

$H_{d}=$ dam height; $D_{c r w}=$ dam crest width; $\alpha=$ upstream slope angle; $\beta=$ downstream slope angle; $Q_{i n}=$ inflow rate into the upstream reservoir; $\rho_{d r y}=$ dry bulk density; $e_{o}=$ initial void ratio; $i_{i n i-1}=$ critical hydraulic gradient for seepage erosion initiation (between sensors $p 1$ and $p 2$ ); $i_{\text {ini-2 }}=$ critical hydraulic gradient for seepage erosion initiation (between sensors $p 2$ and $p 3$ ); $i_{f 1}=$ critical hydraulic gradient for collapse of the dam crest (between sensors $p 1$ and $\left.p 2\right) ; i_{f 2}=$ critical hydraulic gradient for collapse of the dam crest (between sensors $p 2$ and $p 3$ ); $T_{b}=$ time of collapse of the dam crest

respectively. The grain size distribution curves of all the materials used are shown in Fig. 2. The mechanical and hydraulic characteristics of the materials used in the experiments are summarized in Table 4. Silica sand nos. 5 and 8 are generally composed of subangular to angular grains with dry repose angles of 32 and $35^{\circ}$, respectively. Constant-head permeability tests and other soil property tests were carried out on the soils based on the physical conditions (bulk density and antecedent moisture content) used in building the dam models in accordance with standards of the Japanese Geotechnical Society (JGS).

\section{Landslide dam model construction and experimental procedure}

Landslide dam models of different geometries were built approximately $0.4 \mathrm{~m}$ downslope from the upstream water inlet (Fig. 3a). Effort was made in building the dam models so as to simulate naturally existing landslide dam prototypes. Mechanically mixed soils were placed in the flume tank in equal lifts using the moist tamping method. Initially, oven-dried soils were mixed with a known volume of water and then compacted to obtain the desired moisture content and bulk density. All the experiments were conducted with an antecedent moisture content of $5 \%$, except in Exp 8 to 15 where the antecedent moisture content was varied from 5 to $20 \%$. The geometrical characteristics of the dam models are shown in Fig. 3b. The dam height $H_{d}$ and the dam crest width $D_{c r w}$ were varied from 0.15 to $0.3 \mathrm{~m}$ and 0.1 to $0.25 \mathrm{~m}$, respectively. The angles $\alpha$ and $\beta$ representing the upstream and downstream slope angles were varied from 35 to $40^{\circ}$ and 30 to $60^{\circ}$, respectively.

Seven different series of experiments, all summing up to 27 runs of tests, were carried out, each with intent to assess transient pore-water pressure variations and the 
Table 3 Summary of results of critical pore-water pressures and critical seepage velocities obtained from the tests

\begin{tabular}{|c|c|c|c|c|c|c|c|c|}
\hline Test specification & Test no. & $Q_{\text {in }}\left(\mathrm{m}^{3} / \mathrm{s}\right)$ & $\begin{array}{l}p_{\text {crit-1 }} \\
(\mathrm{kPa})\end{array}$ & $\begin{array}{l}P_{\text {crit-2 }} \\
(\mathrm{kPa})\end{array}$ & $\begin{array}{l}P_{\text {crit-3 }} \\
(\mathrm{kPa})\end{array}$ & $\begin{array}{l}V_{\text {crit-1 }} \\
(\mathrm{m} / \mathrm{s})\end{array}$ & $\begin{array}{l}V_{\text {crit-2 }} \\
(\mathrm{m} / \mathrm{s})\end{array}$ & $\begin{array}{l}\text { Characteristic failure } \\
\text { mechanism }\end{array}$ \\
\hline \multirow[t]{3}{*}{ Dam composition } & Exp 1 & $2 \times 10^{-4}$ & 1.30 & 1.24 & 1.08 & $7.10 \times 10^{-6}$ & $5.68 \times 10^{-6}$ & Type I \\
\hline & $\operatorname{Exp} 2$ & $2 \times 10^{-4}$ & 1.64 & 1.49 & 1.38 & $1.14 \times 10^{-6}$ & $5.39 \times 10^{-7}$ & Type /I \\
\hline & Exp 3 & $2 \times 10^{-4}$ & 1.45 & 1.35 & 1.34 & $1.49 \times 10^{-6}$ & $1.21 \times 10^{-6}$ & Transitional: Type // to Type I \\
\hline \multirow{4}{*}{$\begin{array}{l}\text { Rate of inflow into the upstream reservoir } \\
\text { (filling rate) }\end{array}$} & $\operatorname{Exp} 4$ & $1.67 \times 10^{-5}$ & 1.47 & 1.35 & 0.98 & $1.05 \times 10^{-6}$ & $7.39 \times 10^{-7}$ & Type I \\
\hline & $\operatorname{Exp} 5$ & $5 \times 10^{-5}$ & 1.65 & 1.18 & 0.96 & $1.14 \times 10^{-6}$ & $7.15 \times 10^{-7}$ & Type I \\
\hline & $\operatorname{Exp} 6$ & $1 \times 10^{-4}$ & 1.68 & 1.20 & 1.01 & $1.18 \times 10^{-6}$ & $7.85 \times 10^{-7}$ & Type /I \\
\hline & $\operatorname{Exp} 7$ & $1.67 \times 10^{-4}$ & 1.52 & 1.50 & 1.19 & $1.07 \times 10^{-6}$ & $1.01 \times 10^{-6}$ & Type /I \\
\hline \multirow{4}{*}{$\begin{array}{l}\text { Antecedent moisture content at low } \\
\text { compactive effort }\left(e_{0}=1.76\right)\end{array}$} & Exp 8 & $1.5 \times 10^{-4}$ & 1.50 & 1.06 & 1.03 & $1.37 \times 10^{-6}$ & $7.60 \times 10^{-7}$ & Type /l \\
\hline & $\operatorname{Exp} 9$ & $1.5 \times 10^{-4}$ & 1.39 & 1.11 & 1.01 & $1.44 \times 10^{-6}$ & $8.49 \times 10^{-7}$ & Type I \\
\hline & Exp 10 & $1.5 \times 10^{-4}$ & 1.49 & 1.10 & 0.87 & $1.59 \times 10^{-6}$ & $1.02 \times 10^{-6}$ & Typel \\
\hline & Exp 11 & $1.5 \times 10^{-4}$ & 1.43 & 1.12 & 0.83 & $1.30 \times 10^{-6}$ & $9.52 \times 10^{-7}$ & Type I \\
\hline \multirow{4}{*}{$\begin{array}{l}\text { Antecedent moisture content at } \\
\text { high compactive effort }\left(e_{o}=1.21\right)\end{array}$} & Exp 12 & $1.3 \times 10^{-4}$ & 1.41 & 1.20 & 1.15 & $1.29 \times 10^{-6}$ & $7.60 \times 10^{-7}$ & Type /I \\
\hline & Exp 13 & $1.3 \times 10^{-4}$ & 1.40 & 1.19 & 1.02 & $1.28 \times 10^{-6}$ & $7.50 \times 10^{-7}$ & Type /I \\
\hline & Exp 14 & $1.3 \times 10^{-4}$ & 1.38 & 1.22 & 0.99 & $1.08 \times 10^{-6}$ & $8.50 \times 10^{-7}$ & Type II \\
\hline & Exp 15 & $1.3 \times 10^{-4}$ & 1.40 & 1.20 & 0.96 & $1.03 \times 10^{-6}$ & $7.98 \times 10^{-7}$ & Type II \\
\hline \multirow[t]{4}{*}{ Downstream slope angle } & Exp 16 & $1 \times 10^{-4}$ & 1.52 & 1.32 & 1.29 & $9.50 \times 10^{-7}$ & $6.75 \times 10^{-7}$ & Type II \\
\hline & Exp 17 & $1 \times 10^{-4}$ & 1.40 & 1.20 & 1.08 & $9.35 \times 10^{-7}$ & $6.64 \times 10^{-7}$ & Type /l \\
\hline & Exp 18 & $1 \times 10^{-4}$ & 1.44 & 1.06 & 0.83 & $1.30 \times 10^{-6}$ & $4.60 \times 10^{-7}$ & Type I \\
\hline & Exp 19 & $1 \times 10^{-4}$ & 1.50 & 1.03 & 0.99 & $1.28 \times 10^{-6}$ & $5.30 \times 10^{-7}$ & Type I \\
\hline \multirow[t]{4}{*}{ Dam height } & Exp 20 & $1.2 \times 10^{-4}$ & 1.13 & 0.78 & 0.98 & $1.24 \times 10^{-6}$ & $5.99 \times 10^{-7}$ & Type I \\
\hline & Exp 21 & $1.2 \times 10^{-4}$ & 1.48 & 1.21 & 1.22 & $1.38 \times 10^{-6}$ & $8.40 \times 10^{-7}$ & Type /l \\
\hline & Exp 22 & $1.2 \times 10^{-4}$ & 1.60 & 1.40 & 1.29 & $1.40 \times 10^{-6}$ & $8.90 \times 10^{-7}$ & Type II \\
\hline & Exp 23 & $1.2 \times 10^{-4}$ & 1.72 & 1.37 & 1.01 & $1.43 \times 10^{-6}$ & $9.10 \times 10^{-7}$ & Type II \\
\hline \multirow[t]{2}{*}{ Dam crest width } & Exp 24 & $1.67 \times 10^{-4}$ & 1.70 & 1.40 & 1.10 & $1.53 \times 10^{-6}$ & $8.20 \times 10^{-7}$ & Type I \\
\hline & $\operatorname{Exp} 25$ & $1.67 \times 10^{-4}$ & 2.01 & 1.68 & 1.48 & $1.69 \times 10^{-6}$ & $8.55 \times 10^{-7}$ & Type I \\
\hline
\end{tabular}

$Q_{\text {in }}=$ inflow rate into the upstream reservoir; $p_{\text {crit- } 1}=$ critical pore-water pressure for collapse of the dam crest at $p 1 ; p_{\text {crit- } 2}=$ critical pore-water pressure for collapse of the dam crest at $p 2 ; p_{c r i t-3}=$ critical pore-water pressure for collapse of the dam crest at $p 3 ; V_{c r i t-1}=$ critical seepage velocity (between sensors $p 1$ and $p 2) ; V_{c r i t-2}=$ critical seepage velocity (between sensors $p 2$ and $p 3$ )

critical hydraulic gradients for seepage erosion initiation and dam failure under steady-state seepage. The main experiments were conducted after carrying out a series of initial tests which were mostly done to check sensor reliability, result validation, test repeatability and selection of appropriate mixtures of materials. However, the results of experiments conducted on dams built with dam crest width $D_{c r w}$ of 0.1 and $0.15 \mathrm{~m}$ are excluded in this paper due to some challenges posed by the monitoring sensors. The initial conditions set for all the tests assumed that the upstream reservoir was empty. Filling of the upstream reservoir was carried out with a rubber hose attached to a water tap, and connected to a manually-operated flowmeter. A steady-state seepage through the dam models was achieved by ensuring that the upstream reservoir level remained constant at approximately two-thirds of the dam height. Real-time data was acquired by connecting all the sensors to a

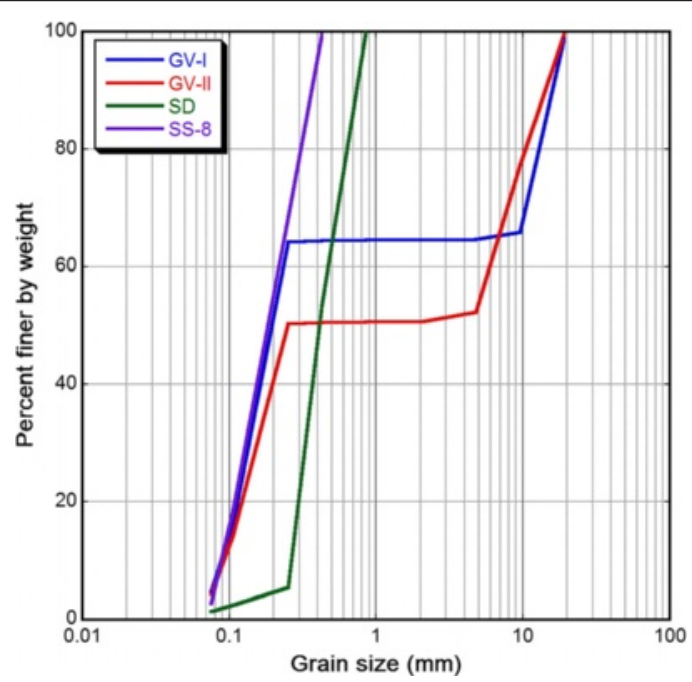

Fig. 2 Grain size distribution curves of the dam materials. GV-I Gravelly dam I, GV-Il Gravelly dam II, SD Sandfill dam, SS-8 Silica sand no. 8 
Table 4 Mechanical and hydraulic characteristics of the materials used in the experiments

\begin{tabular}{|c|c|c|c|c|c|c|c|c|c|}
\hline Sample name & Test no. & Sediment mixture (\%) & $D_{50}(\mathrm{~mm})$ & $C_{u}$ & $C_{c}$ & Gravel (\%) & Sand $(\%)$ & Fines (\%) & $K(\mathrm{~m} / \mathrm{s})$ \\
\hline Sandfill dam (SD) & Exp 1 & Silica sand $5(100)$ & 0.799 & 2.474 & 1.385 & - & 99.5 & 0.5 & $5.5 \times 10^{-4}$ \\
\hline Gravelly dam I (GV-I) & Exp 2 & Silica sand 8-gravel mix (40:60) & 0.284 & 79.870 & 0.069 & 34 & 49.6 & 16.4 & $3.8 \times 10^{-5}$ \\
\hline Gravelly dam II (GV-II) & Exp 3 & Silica sand 8-pebbles-gravel mix (30:30:40) & 0.201 & 3.520 & 1.047 & 22.6 & 62.9 & 14.5 & $6.0 \times 10^{-5}$ \\
\hline Silica sand no. 8 & Exp $4 \sim 25$ & Silica sand $8(100)$ & 0.124 & 1.726 & 1.195 & - & 67.1 & 32.9 & $5.8 \times 10^{-}$ \\
\hline
\end{tabular}

$D_{50}=$ median grain size; $C_{u}=$ coefficient of uniformity; $C_{c}=$ coefficient of curvature; $K=$ coefficient of permeability

standard high-speed monitoring and recording workstation comprised of two synchronized universal recorders $(P C D$ $330 B-F)$ and a laptop computer. Sampling frequency was set at $50 \mathrm{~Hz}$ for all the tests.

At the beginning of each experiment, discharge into the upstream reservoir was set at the desired value using a manually-operated flowmeter. The discharge was maintained until the upstream reservoir level equaled two-thirds of the dam height. Afterward, an equilibrium hydraulic head was established by ensuring that the upstream reservoir level remained constant prior to the collapse of the dam crest. The change from unsaturated to saturated state began during the filling of the upstream reservoir. Consequently, loss of matric suction due to positive pore-water pressure buildup under steady-state seepage, as observed from sensor p3 (Fig. 4), marked the onset of static liquefaction and exfiltration of water from the downstream toe, which further led to debris flow mobilization and dam failure.

\section{Determination of critical hydraulic gradients}

Variations in hydraulic gradients $\left(i_{1}\right.$ and $\left.i_{2}\right)$ through the dam models were determined from pore-water pressure values obtained from the experiments. Darcy (1856) in Fredlund et al. (2012) postulated that the rate of water flow through a soil mass was equal to the hydraulic gradient, as described by the equation:

$$
v_{w}=-k_{w} \frac{\partial h_{w}}{\partial z}
$$

where $v_{w}=$ flow rate of water $\left(\mathrm{m}^{3} / \mathrm{s}\right), k_{w}=$ coefficient of permeability with respect to the water phase $(\mathrm{m} / \mathrm{s}), \partial h_{w} /$ $\partial z=$ hydraulic gradient in the $\mathrm{z}$-direction. Hydraulic heads, $h_{1}, h_{2}$, and $h_{3}$ at three different locations within the dam models were computed from pore-water pressure values using the following equation (Fig. 4):

$$
h=\frac{u_{w}}{\gamma_{w} \cos ^{2} \psi}
$$

where $u_{w}=$ pore-water pressure $(\mathrm{kPa}), \gamma_{w}=$ unit weight of water $\left(\mathrm{kN} / \mathrm{m}^{3}\right), \psi=$ flume bed slope angle (degree). Therefore, hydraulic gradient $i_{1}$ between sensors $p 1$ and $p 2$ was determined as described by the equation below:

$$
i_{1} \approx \frac{-\left[\left(h_{2}+h_{02}\right)-\left(h_{1}+h_{01}\right)\right]}{L_{1} / \cos \psi}
$$

Similarly, the hydraulic gradient, $i_{2}$ between sensors $p 2$ and $p 3$ was determined as follows:

$$
i_{2} \approx \frac{-\left[\left(h_{3}+h_{03}\right)-\left(h_{2}+h_{02}\right)\right]}{L_{2} / \cos \psi}
$$

where $h_{01}, h_{02}$ and $h_{03}$ represent corresponding vertical

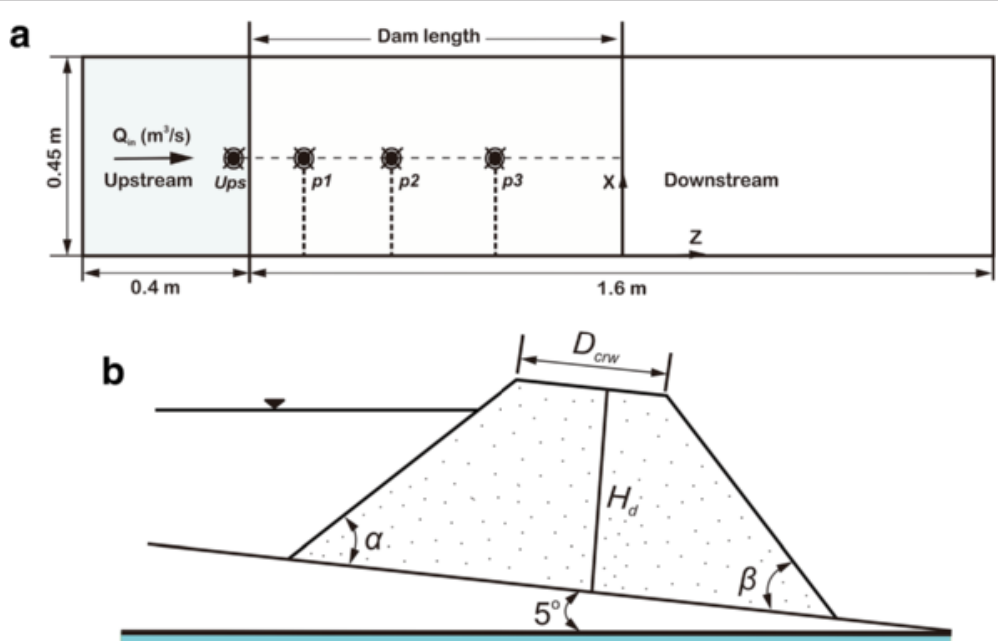

Fig. 3 a Plan view of the flume tank indicating the position of the dam model and monitoring sensors. $\mathbf{b}$ Schematic diagram of the dam geometry (not to scale) 


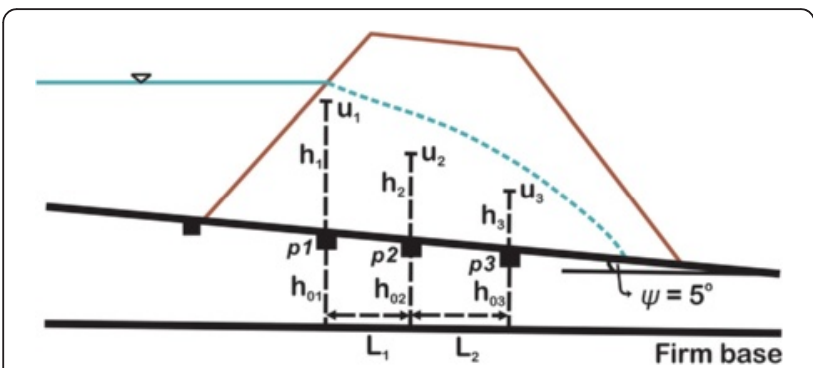

Fig. 4 Schematic diagram for the determination of hydraulic gradients

distances between the flat firm base and the slope bed, whereas $L_{1}$ and $L_{2}$ are horizontal distances between $p 1$ and $p 2$, and $p 2$ and $p 3$, respectively. Two limit values of hydraulic gradients, corresponding to the onset of initiation of seepage erosion $i_{i n i}$ and collapse of the dam crest $i_{f}$ were determined based on results obtained from the initial tests.

\section{Results and discussion}

\section{General characteristics of the experiments}

Two characteristic types of dam failure (Type I and Type II) were observed during the experiments and were found to depend on the geometry and hydromechanical characteristics of the dam materials. These were further subdivided into several interrelated failure processes which included wetting front propagation, downstream slope saturation, exfiltration, sapping/seepage-face erosion, toe bifurcation, undermining and progressive sloughing of the downstream face, and late-stage overtopping.

Type I involves failures which could be related to static liquefaction of the soil mass under steady-state seepage that reduced the apparent cohesion of the soil and led to debris flow mobilization. This type of failure was primarily initiated by sapping erosion which occurred as a result of steady exfiltration of water from the downstream toe; which by extension, triggered gradual undercutting and debuttressing of the downstream slope as the mobilized mass 'flowed' downstream, thus lowering the dam height (Fig. 5a). Dam failure occurred by overtopping as the upstream reservoir level reached the tip of the partially saturated dam material, eroding the entire crest to form a wide breach channel. This type of failure was characteristic of experiments conducted with low upstream inflow rates, low compactive effort $\left(e_{o}=1.76\right)$, high downstream slope angle $\left(\beta \geq 40^{\circ}\right)$, and dam crest width greater than $0.15 \mathrm{~m}$.

Type II involves failures triggered by downslope propagation of the wetting front and subsequent mobilization of the fluidized material at the upper part of the downstream face. This failure mechanism was characterized by downstream toe bifurcation and abrupt collapse of a large flank of the slope due to intense saturation which originated from the dam crest and progressed towards the downstream toe (Fig. 5b). Dam failure occurred by the formation of a hydraulic crack aligned perpendicular to the downstream face due to the reduction of the effective stress of the soil. This type of failure occurred mostly in dams of low downstream slope angle $\left(\beta \geq 40^{\circ}\right)$, high shear strength of the soil relative to the shear stress of the seeping water, and high compactive effort $\left(e_{o}=1.21\right)$.

\section{Influence of dam composition}

Three types of materials (SD, GV-I, and $G V-I I)$ were used to investigate transient changes in pore-water pressures and variations in hydraulic gradients under steadystate seepage through the dam models (Exp 1 3; Table 2 and 3). The dam models were built to obtain initial void ratios of $1.41,0.71$ and 0.84 for $S D, G V-I$, and $G V-I I$ materials, respectively. The resulting trends of porewater pressures within the dam models indicate gross anisotropy and heterogeneity in dams composed of $G V-I$ and $G V-I I$, whereas the low critical pore-water pressures obtained in the dam built with homogeneous $S D$ material demonstrates the liquefaction potential of cohesionless and isotropic sands (Fig. 6). The failure mechanism of the $S D$ dam was basically characteristic of the Type $I$ failure pattern. Enlargement of the sapping zone was characterized by occasional mass failures which were enhanced by a decrease in the effective stress of the soil as the energy of the exfiltrating water increased. In contrast, GV-I material showed Type II failure mechanism, whereas the failure mechanism of $G V-I I$ material evolved from Type II to Type I (Fig. 7). Critical pore-water pressure values $\left(p_{\text {crit- } 1}\right)$ determined at $p 1$, which correspond to the onset of failure of the dams were 1.30, 1.64 and $1.45 \mathrm{kPa}$ for $S D, G V-I$, and $G V-I I$, respectively. The observed trends of pore-water pressures within the dams were found to be inversely proportional to the initial void ratio $e_{o}$ (Table 3 ), and directly proportional to the coefficient of uniformity $C_{u}$ of the dam materials (Table 4). This could be potentially caused by capillary rise within the materials which depends on the grain size distribution and bulk density of the constituent soil mass that, in itself, affected the porosity of the soil. Thus, the stability and deformation characteristics of the dams increased as the grain size distribution changed from poorly to well graded. Similarly, the critical hydraulic gradients for seepage erosion initiation $i_{i n i}$, increased with a decrease in pore size, while the critical hydraulic gradient for collapse of the dam crest $i_{f}$ was influenced by the grain size distribution. The effect of grain size distribution on the development of seepage in the dams was evidenced by the variations in seepage velocity as the dynamics of the seeping water changed from laminar flow to turbulent flow (Table 3; Additional file 1: Video S1). The fact that the longevity of the dam built with GV-II material $\left(v_{\text {crit-2 }}, 1.21 \times 10^{-6} \mathrm{~m} / \mathrm{s}\right)$ was higher than those built with $S D$ and $G V-I$ materials $\left(v_{\text {crit-2 }}, 5.68 \times 10^{-6}\right.$ and $5.39 \times 10^{-6} \mathrm{~m} / \mathrm{s}$, respectively) demonstrates that other 

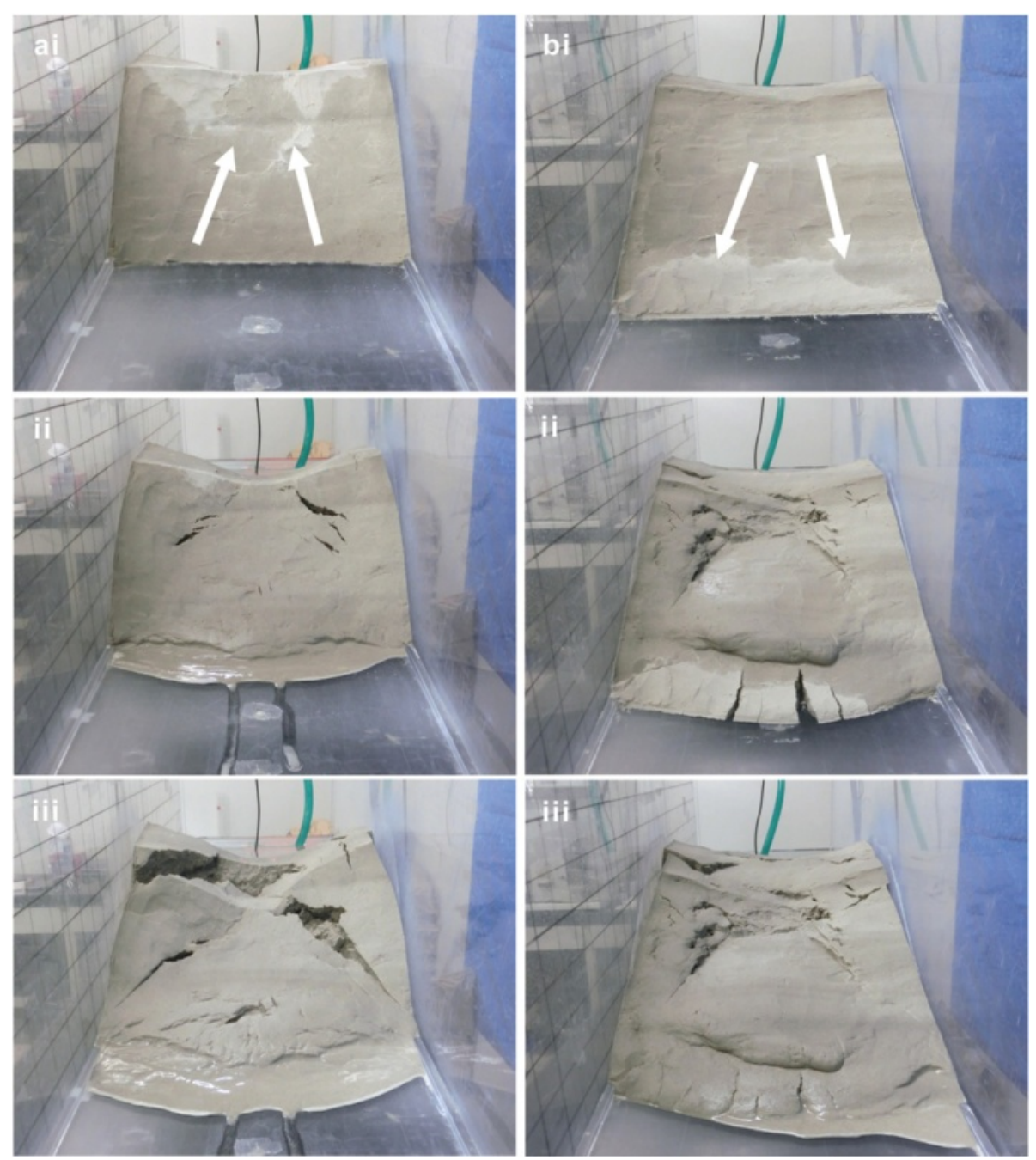

Fig. 5 Typical failure mechanisms of the dams. a Type I - Upslope propagation of wetting front, exfiltration, sapping and sloughing of the fluidized soil mass. b Type II - Downslope propagation of wetting front, bifurcation, and undermining of the slope toe

physical parameters such as particle density, hydraulic conductivity and gravel content affect seepage development in landslide dams and soil slopes (Kokusho and Fujikura 2008).

\section{Rate of inflow into the upstream reservoir}

Exp 4 7 were conducted to evaluate the influence of inflow rate $Q_{\text {in }}$ into the upstream reservoir. The dam models were built with uniform geometrical and physical characteristics (Table 2). Figure 8 shows the variations in pore-water pressures through the dams at steady-state inflow rates of $1.67 \times 10^{-5} \mathrm{~m}^{3} / \mathrm{s}, 5 \times 10^{-5} \mathrm{~m}^{3} / \mathrm{s}, 1 \times 10^{-4} \mathrm{~m}^{3} / \mathrm{s}$, and $1.67 \times$ $10^{-4} \mathrm{~m}^{3} / \mathrm{s}$. The filling rate of the upstream reservoir initiated seepage processes that changed the dynamics of the pore-water pressures. The critical hydraulic gradients for initiation of seepage erosion $\left(i_{\text {ini-1 }}\right.$ and $\left.i_{\text {ini-2 }}\right)$ varied from 0.067 to 0.122 . A low $p_{\text {crit- } 1}$ value of $1.52 \mathrm{kPa}$ was determined in the experiment conducted with $Q_{i n}$ of $1.67 \times 10^{-4}$ $\mathrm{m}^{3} / \mathrm{s}$, relative to $Q_{\text {in }}$ of $5 \times 10^{-5} \mathrm{~m}^{3} / \mathrm{s}\left(p_{\text {crit }-1}=1.65 \mathrm{kPa}\right)$ and $1 \times 10^{-4} \mathrm{~m}^{3} / \mathrm{s}\left(p_{\text {crit }-1}=1.68 \mathrm{kPa}\right)($ Table 3$)$. This could be attributed to a rapid increase in the hydraulic head which initiated high seepage gradients that reduced the effective stress of the soil, leading to differential settlement, hydraulic cracking, and lowering of the dam crest. Thus, the rate of reduction of the shear strength of the soil due to a decrease in matric suction depends on the rate of inflow into the upstream reservoir $Q_{i n}$ and the rate of propagation of the wetting front. Trends of hydraulic gradients through the dams indicate that $i_{f 1}$ decreased with an increase in $Q_{i n}$, whereas $i_{f 2}$ increased with an increase in $Q_{i n}$, suggesting a corresponding increase in seepage velocity between sensors $p 1$ and $p 2$ (Table 2; Fig. 13 in Appendix 1). Critical seepage velocities determined from the tests show that $v_{\text {crit-2 }}$ increased from $7.39 \times 10^{-7} \mathrm{~m} / \mathrm{s}$ for $Q_{\text {in }}$ of $1.67 \times 10^{-5} \mathrm{~m}^{3} / \mathrm{s}$ to $1.01 \times 10^{-6} \mathrm{~m} / \mathrm{s}$ for $Q_{\text {in }}$ of $1.67 \times 10^{-4} \mathrm{~m}^{3} / \mathrm{s}$. 

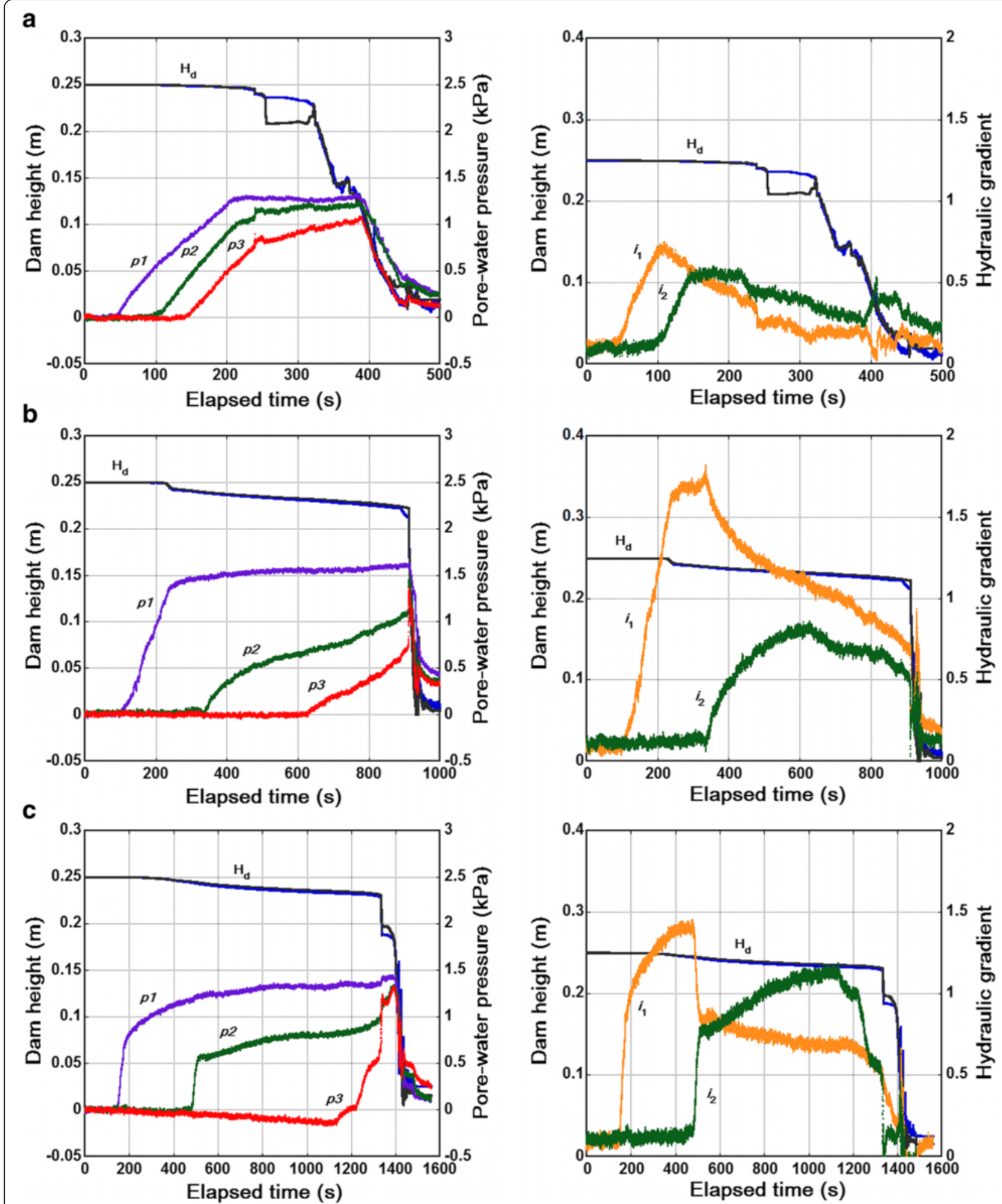

Fig. 6 Time-dependent transient changes in pore-water pressures and trends of hydraulic gradients in dams built with (a) Sandfill dam (b) Gravelly dam I and (c) Gravelly dam II 


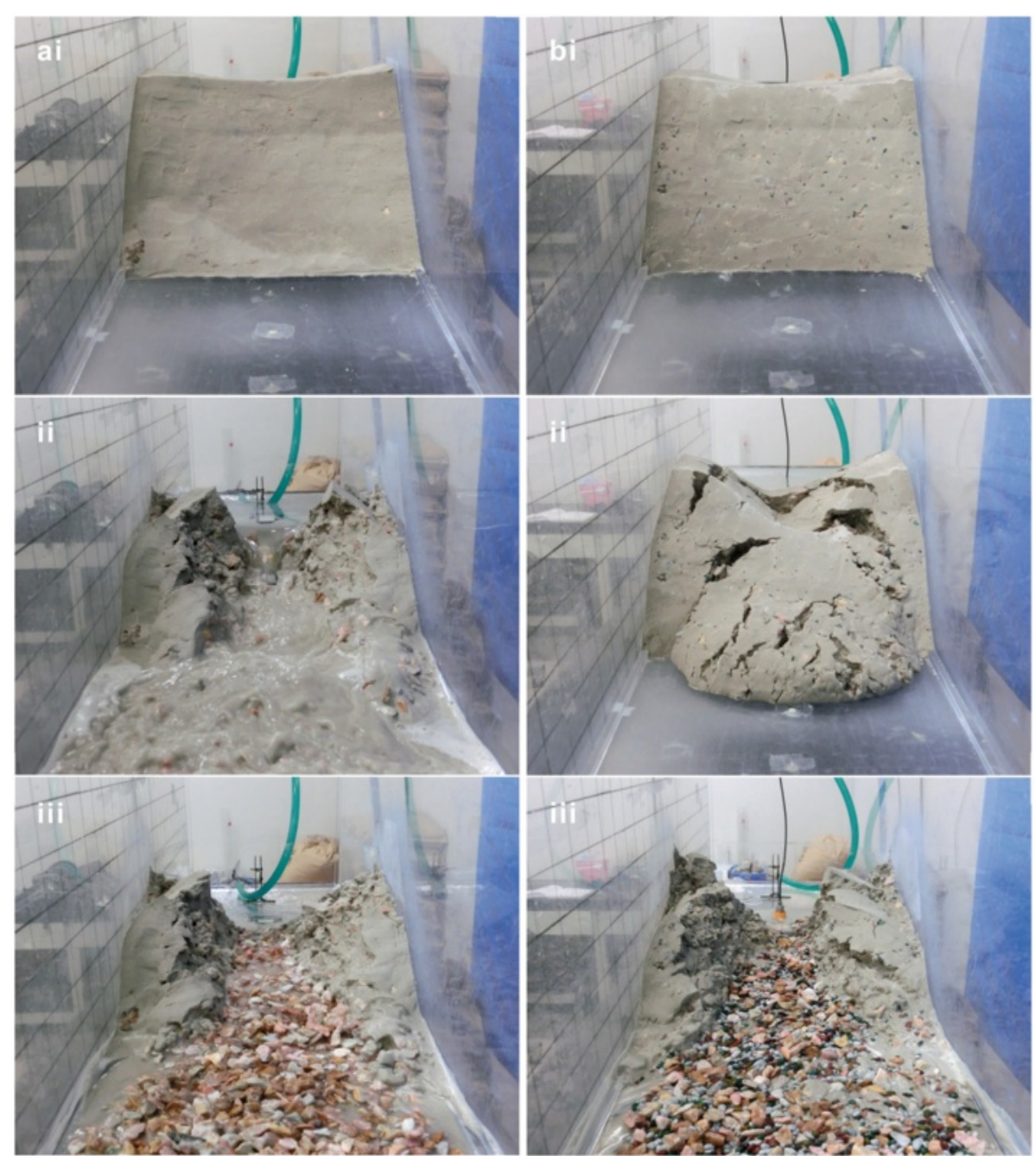

Fig. 7 Images of seepage-induced failure of dams built with (a) Gravelly dam I and (b) Gravelly dam II

Exfiltration, sapping and undercutting of the downstream toe, characteristic of Type I failure mechanism, occurred at low inflow rates as a result of low seepage processes that led to liquefaction and collapse of the dam crest (Exp 4 and 5). In contrast, hydraulic cracking, downstream face saturation, and toe bifurcation characteristic of Type II failure mechanism, occurred in experiments conducted with high inflow rates $(\operatorname{Exp}$ 6 and 7). The experimental results demonstrate that the stability and time of collapse of the dam crest $T_{b}$ decreased with an increase in inflow rate into the upstream reservoir. This was evidenced by the characteristic failure mechanism of the dam models which evolved from Type I to Type II with a corresponding increase in $Q_{\text {in }}$ (Table 3).

\section{Influence of material condition}

Soil wetting is a major cause of shear strength reduction and volume change in unsaturated soils and is a common occurring factor in collapsible soils and expansive soils. Exp 8 11 were conducted to assess the influence of antecedent moisture content $w$ on the deformation behaviour of landslide dams under steady-state seepage. Antecedent moisture contents of the soils were increased by $5 \%$ during soil preparation and dam model construction. Figure 9 shows the resulting trends of hydraulic gradients through the dams. A linear relationship was observed between the antecedent moisture content and the rate of deformation and collapse of the dam models (Fredlund 1999). It is noteworthy to mention that the critical hydraulic gradients $\left(i_{f 1}\right.$ and $\left.i_{f 2}\right)$ coincided with the onset of dam deformation and crest settlement. Measured critical hydraulic gradients for seepage erosion initiation varied from 0.053 to 0.118 , while the critical hydraulic gradient for failure of the dams increased with an increase in antecedent moisture content. Similarly, the reduction of capillary forces due to an increase in soil moisture content caused the critical seepage velocity to decrease from $1.31 \times 10^{-6} \mathrm{~m} / \mathrm{s}$ for 
a

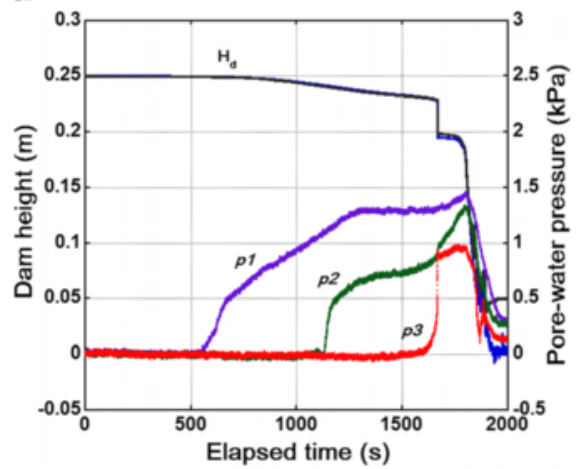

C

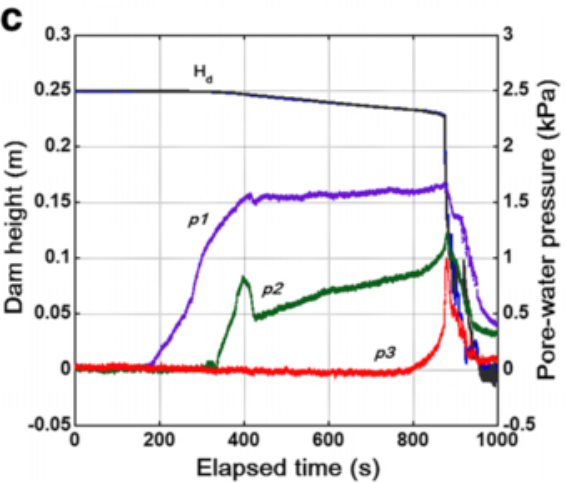

b

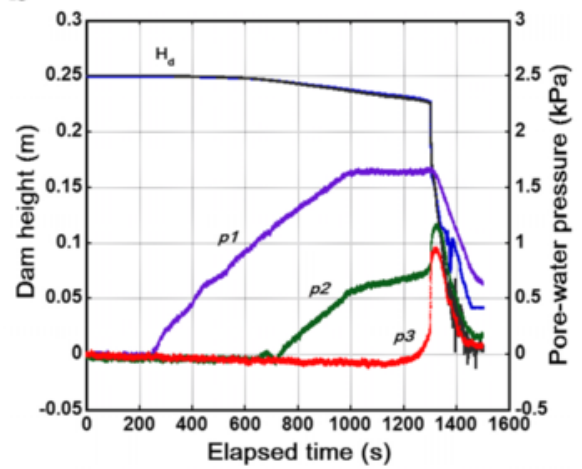

d

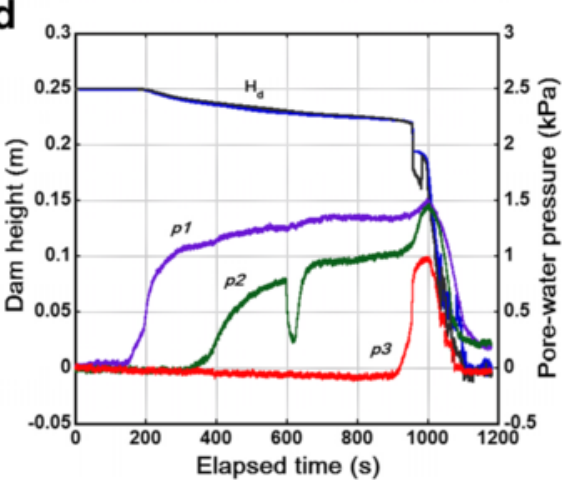

Fig. 8 Transient variations in pore-water pressures in experiments conducted with upstream inflow rates of (a) $1.67 \times 10^{-5} \mathrm{~m}^{3} / \mathrm{s}(\mathbf{b}) 5 \times 10^{-5} \mathrm{~m}^{3} / \mathrm{s}$ (c) $1 \times 10^{-4} \mathrm{~m}^{3} / \mathrm{s}$ (d) $1.67 \times 10^{-4} \mathrm{~m}^{3} / \mathrm{s}$
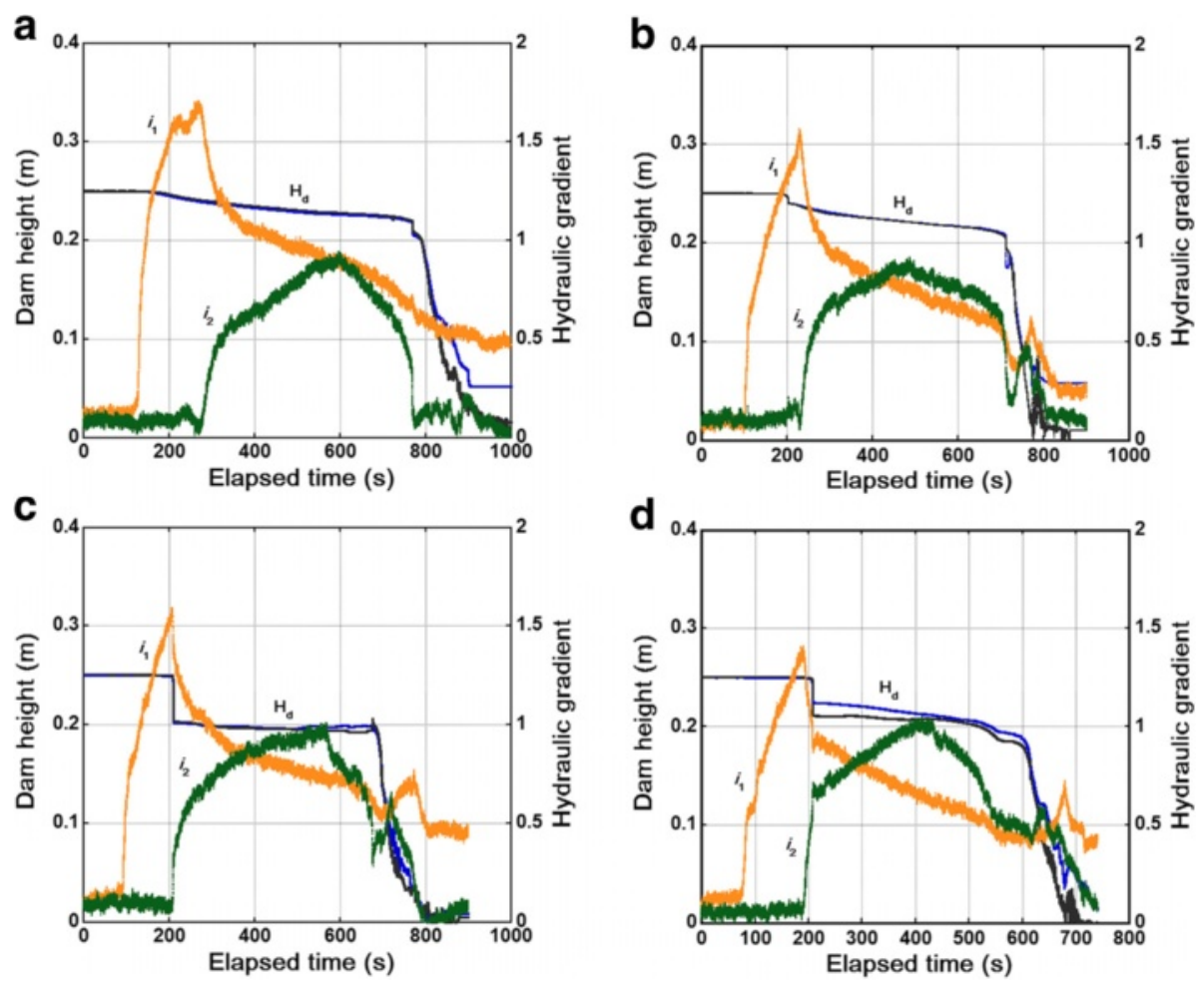

Fig. 9 Trends of hydraulic gradients in dams built with an $e_{0}$ of 1.76 and antecedent moisture contents of (a) $5 \%$ (b) $10 \%$ (c) $15 \%$ (d) $20 \%$ 
$w=5 \%$ to $9.52 \times 10^{-7} \mathrm{~m} / \mathrm{s}$ for $w=20 \%$. The failure mechanism of the dams evolved from Type II to Type I as antecedent moisture content increased through the dams. The rate of exfiltration and sapping erosion at the downstream toe increased from low saturated soils to highly saturated soils. This was attributed to the reduction of matric suction caused by wetting resulting in high void ratios that accentuated the abrupt collapse of the dams.

Figure 10 shows trends of hydraulic gradients and the failure mechanism of dam models built with the same antecedent moisture contents $(5,10,15$ and $20 \%)$, but packed at a higher compactive effort, $e_{o}=1.21(\operatorname{Exp} 12 \sim 15)$. The characteristic trends displayed by the hydraulic gradients, as well as the low critical seepage velocities determined from the experiments indicate, that the initial void ratio $e_{o}$ of the soil affected the failure mechanism of the dams. It may be important to note that $i_{f 1}$ and $i_{f 2}$ increased with an increase in antecedent moisture content, thus suggesting that the dynamics of the seeping water were mainly characteristic of a laminar flow. The stability of the dam models increased as antecedent moisture content decreased from 20 to $5 \%$, as observed from $T_{b}$ and $p_{c r i t-3}$, and thus indicates the effect of pore-water pressures in reducing the effective stress of the soil (Tables 2 and 3). This effect can be related to the influence of matric suction on the liquefaction potential and shear strength reduction in partially saturated soils (Simon and Collison 2001; Okamura and
Soga 2006). Comparison between Exp 8 11 and Exp 12 15 shows that the deformation and collapse mechanism of the dam models were more pronounced in dams with an $e_{o}$ of 1.76 (Exp 8 11) than in those with an $e_{o}$ of 1.21 (Exp $12 \sim 15$ ) (Figs. 16 and 17 in Appendix 2). Similarly, a comparison between the critical hydraulic gradients measurements in Exp 8 11 and Exp 12 15 shows that the critical hydraulic gradient decreased with a decrease in initial void ratio. The observed trends of wetting front propagation and the transient changes in pore-water pressures suggest that seepage flow through the dam materials was not essentially controlled by matric suction but by a hydraulic head gradient (Fredlund and Rahardjo 1993).

\section{Influence of dam geometry}

The geometry of landslide dams is one of the major factors contributing to seepage erosion and slope instability. The two major factors that control the critical hydraulic gradient for instability in soil slopes are the downstream slope angles $\beta$ and the gradient of the soil layer $\psi$ (Iverson and Major 1986; Budhu and Gobin 1996). Basically, the internal friction angle of a dry cohesionless soil, at zero external pressure, is equal to the maximum stable slope angle of the soil. However, the soil mass collapses to a lower slope angle if steady-state seepage occurs. A series of experiments were conducted to evaluate the effects of downstream
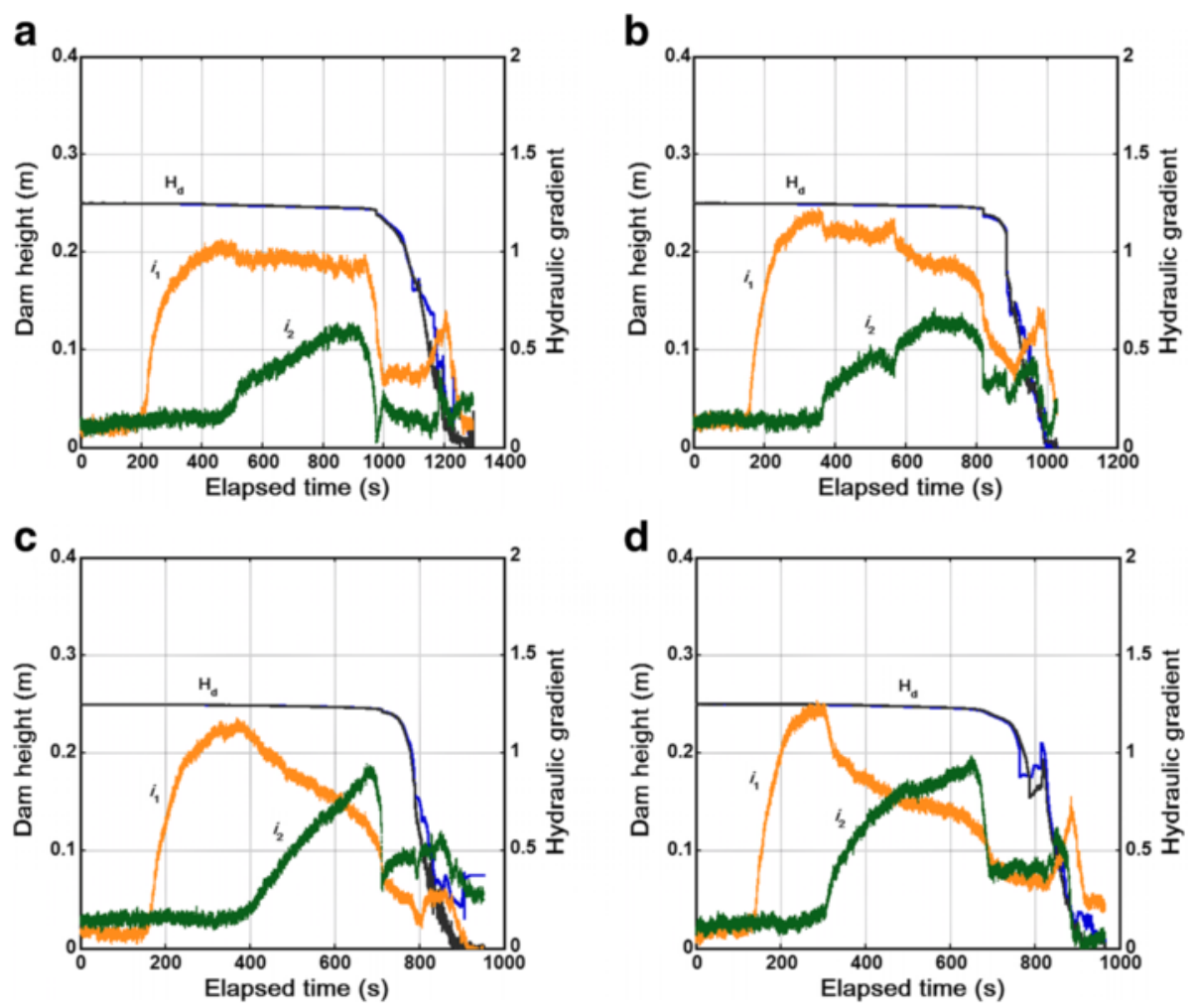

Fig. 10 Trends of hydraulic gradients in dams built with an $e_{0}$ of 1.21 and antecedent moisture contents of (a) $5 \%$ (b) $10 \%$ (c) $15 \%$ (d) $20 \%$ 
slope angle $\beta$ on the critical hydraulic gradients for failure of landslide dams (Exp 16 19). The downstream slope angles were varied from 30 to $60^{\circ}$. A close examination of the results indicates that the stability of the dams increased as the downstream slope angle decreased from 60 to $30^{\circ}$ (Table 2). The time of collapse of the dam crest increased from $\beta=60^{\circ}\left(T_{b}\right.$, $900 \mathrm{~s})$ to $\beta=30^{\circ}\left(T_{b}, 2300 \mathrm{~s}\right)$. Similarly, $i_{f 1}$ increased with an increase in $\beta$, whereas $i_{f 2}$ decreased with an increase in $\beta$ (Fig. 14 in Appendix 1). Also, the critical seepage velocity decreased with an increase in $\beta$, indicating high failure potentials in dams of high downstream slope angles (Table 3). The variations in pore-water pressures and the failure mechanism of the dams are shown in Fig. 18 (Appendix 2). The failure mechanism of the dams built with $\beta$ in the range of 30 to $40^{\circ}$ was initiated by the bifurcation of the downstream toe (Type II), whereas exfiltration, sapping and undermining of the downstream toe were characteristic of dams with $\beta$ in the range of 41 to $60^{\circ}$ (Type I). Budhu and Gobin 1996 remarked that for a soil which has $\phi$ of $30^{\circ}$, the exit hydraulic gradient at the slope face increases from 1 (when $\lambda=\beta$ ) to a limit value of $\sin \beta$ (when $\lambda=90^{\circ}$ ).

The influence of dam height on the stability and longevity of landslide dams under steady-state seepage was evaluated in dams built with different dam heights $H_{d}$, ranging from
$0.15 \mathrm{~m}$ to $0.3 \mathrm{~m}$ (Tables 2 and 3). The experiments were conducted at a constant upstream inflow rate of $1.2 \times 10^{-4}$ $\mathrm{m}^{3} / \mathrm{s}$ (Exp 20 23). A positive correlation was observed between the critical hydraulic gradients for dam failure $i_{f 1}$ and $i_{f 2}$ ) and the dam height. The values of $i_{f 1}$ and $i_{f 2}$ increased from 1.17 and 0.55 for $H_{d}=0.15 \mathrm{~m}$, to 1.35 and 0.85 for $H_{d}=0.30 \mathrm{~m}$ (Table 2; Fig. 15 in Appendix 1). Critical pore-water pressure values correlating with the onset of failure of the dams increased from $1.13 \mathrm{kPa}\left(H_{d}=0.15 \mathrm{~m}\right)$ to $1.72 \mathrm{kPa}\left(H_{d}=0.30 \mathrm{~m}\right)$ (Fig. 19 in Appendix 2). The results show that at constant $\alpha$ and $\beta$, the stability of the dams increased with a decrease in dam height $H_{d}$. This was further evidenced by the failure mechanism of the dams which evolved from Type $I$ for $H_{d}=0.15 \mathrm{~m}$ to Type II for $H_{d}=0.30 \mathrm{~m}$. The results indicate that the height of landslide dams is an important parameter for assessing the stability of natural river blockages.

Exp 24 25 were conducted to evaluate the influence of dam crest width $D_{c r w}$ on the failure mechanism of landslide dams. A steady-state seepage was maintained at a constant upstream inflow of $1.67 \times 10^{-4} \mathrm{~m}^{3} / \mathrm{s}$. The results of transient variations in pore-water pressures and the corresponding trends of hydraulic gradients in the dams built with $D_{c r w}$ of $0.20 \mathrm{~m}$ and $0.25 \mathrm{~m}(\operatorname{Exp} 24$ and 25$)$ are shown in Fig. 11. The critical hydraulic gradients for seepage erosion initiation ( $i_{\text {ini-1 }}$ and $\left.i_{\text {ini-2 }}\right)$, varied from 0.081 to 0.118 . Exfiltration, sapping and debuttressing of the downstream toe, characteristic
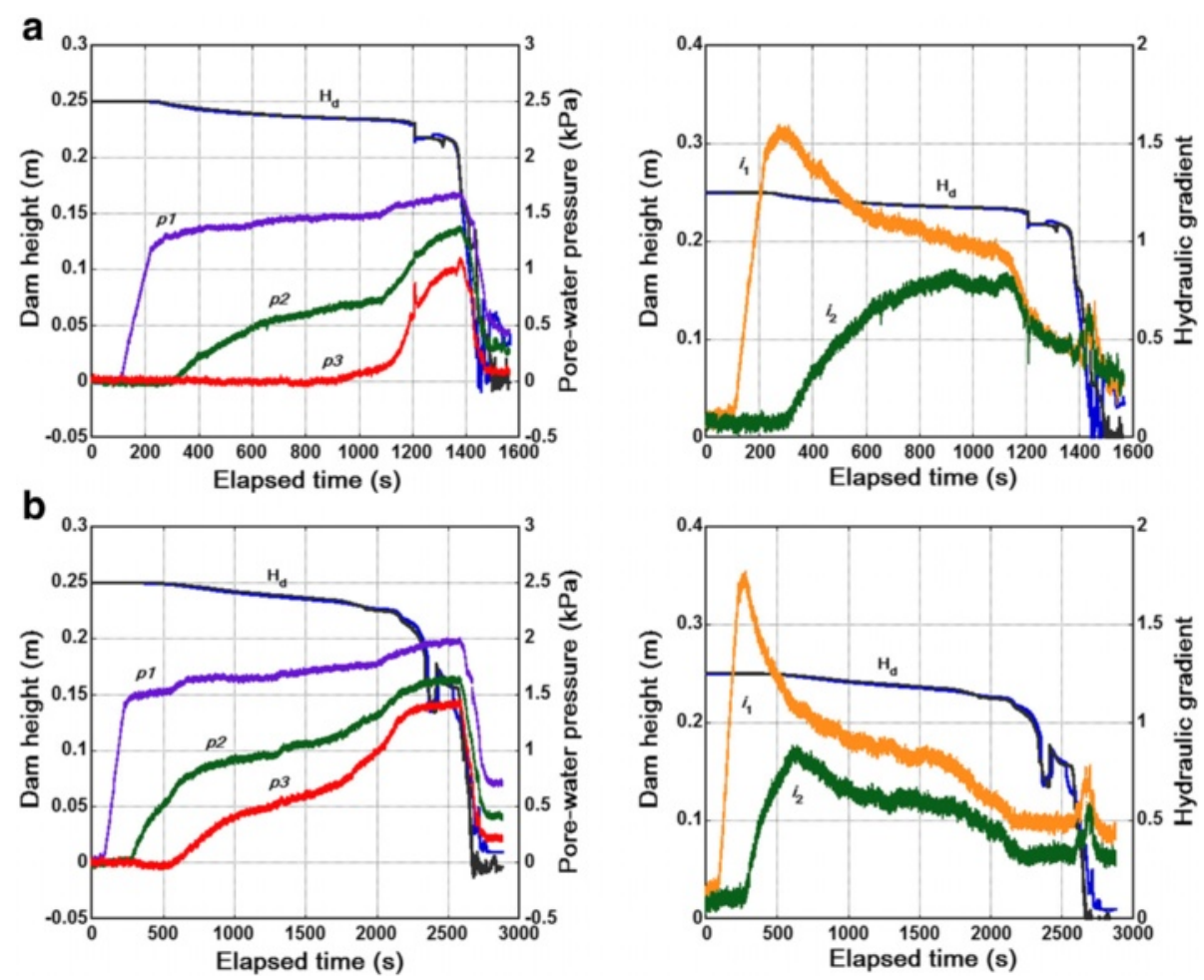

Fig. 11 Evolution of pore-water pressures and hydraulic gradients in dams built with dam crest widths of (a) $0.20 \mathrm{~m}$ (b) $0.25 \mathrm{~m}$ 
of Type I failure pattern, were the major failure mechanisms of the dams (Fig. 12). The rate of propagation of the wetting front through the dams was strongly influenced by $D_{c r w} / H_{d}$. High $D_{c r w} / H_{d}$ resulted in high values of $i_{f 1}, i_{f 2}$, and $v_{c r i t}$. The continual propagation of wetting front through the dams resulted in a gradual reduction of the effective stress of the soil, and subsequent mobilization of the liquefied mass which travelled downstream with an initial speed of $1.2 \times 10$ ${ }^{-5} \mathrm{~m} / \mathrm{s}$. The episodic occurrence of hydraulic cracks and undermining and sloughing of the fluidized slope mass continued until the dam breached by overtopping. The results demonstrate that at constant hydraulic and geometrical conditions $\left(H_{d}, \alpha\right.$ and $\left.\beta\right), i_{f 1}$ and $i_{f 2}$, as well as $v_{c r i t}$ increased with an increase in $D_{c r w}$, indicating that the critical seepage velocity and the critical hydraulic gradient for seepage erosion in landslide dams are influenced by dam crest width $D_{c r w}$ and $D_{c r w} / H_{d}$.

\section{Conclusions}

An extensive experimental programme was carried out to investigate the effects of transient variations in porewater pressures and the critical hydraulic gradients for seepage-induced failure of landslide dams using a flume tank specifically designed for accurate determination of these hydraulic parameters. A steady-state seepage was maintained by ensuring that the upstream reservoir level remained constant prior to the collapse of the dam crest. Limit values of hydraulic gradients and seepage velocities were determined for different hydromechanical and geometrical conditions. Based on the experimental results, the following conclusions can be drawn:

1. Sapping was the most dominant mechanism of slope destabilization observed in all the experiments. Other significant interrelated failure processes of the dam models included wetting front propagation, downstream face saturation, exfiltration, hydraulic cracking, toe bifurcation, downstream slope undercutting, sloughing and late-stage overtopping.

2. Two characteristic types of failure, which depend on the geometrical and hydromechanical properties of the dams were observed: Type I and Type II. Type I commonly occurred in dams built with low compactive effort $\left(e_{o}=1.76\right)$, high downstream slope angle $\left(\beta \geq 40^{\circ}\right)$, crest width greater than $0.15 \mathrm{~m}$, and moisture content lower than $15 \%$. This type of failure was initiated by exfiltration, sapping, and upslope propagation of the wetting front towards the dry upper region of the dam crest. Type I failure mechanism shares similar characteristics to the three distinct zones of slope deformation triggered by sapping, which are: fluvial, sapping and undermining zones, as reported by Howard and McLane (1988). In contrast, Type II was found in dams of low downstream slope angle $\left(\beta \geq 40^{\circ}\right)$, dam height greater than $0.25 \mathrm{~m}$, high upstream inflow rates and high compactive effort $\left(e_{o}=1.21\right)$. Failure in these dams was triggered by downslope propagation of the wetting front, bifurcation of the damp lowermost
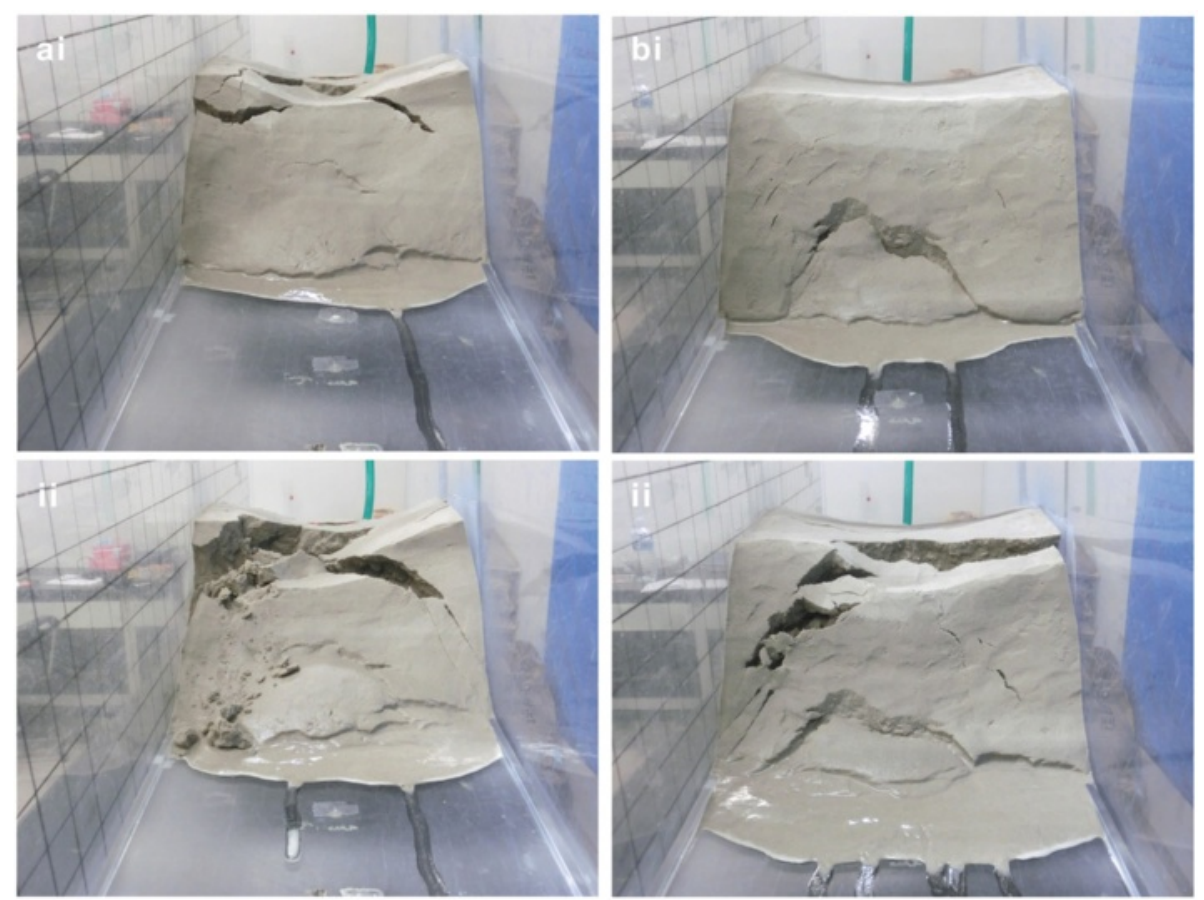

Fig. 12 Exfiltration, sapping and downstream toe debuttressing under steady-state seepage in dams built with dam crest widths of (a) $0.20 \mathrm{~m}$ (b) $0.25 \mathrm{~m}$ 
part of the downstream toe, sapping erosion and sloughing of the fluidized slope material.

3. The build-up of positive pore-water pressure under steady-state seepage and its effects on the apparent cohesion of the soil were evaluated for different upstream inflow rates and antecedent moisture contents. The results indicated that the stability and longevity of the dam models increased with a decrease in upstream inflow rate and antecedent moisture content. Thus, demonstrating the significance of pore geometry, particle density, gradation, and hydraulic conductivity of materials forming landslide dams in the development of seepage processes.

4. In all the experiments, the critical hydraulic gradients for seepage erosion initiation $\left(i_{\text {ini-1 }}\right.$ and $\left.i_{\text {ini-2 }}\right)$ ranged from 0.042 to 0.147 . The critical hydraulic gradient for collapse of the dam crest $i_{f}$ was strongly influenced by several factors, such as the initial void ratio (compactive effort), antecedent moisture content, particle density, grain size distribution, inflow rate into the upstream reservoir and the geometrical characteristics of the dams.

5. In the dams built with mixed materials, $i_{f 1}$ and $i_{f 2}$ increased with an increase in uniformity coefficient. The critical hydraulic gradient for collapse of the dam crest $i_{f}$ increased with an increase in inflow rate into the upstream reservoir (filling rate). Similarly, $i_{f 1}$ and $i_{f 2}$ were controlled by the combined effects of antecedent moisture content and porosity of the soil. At low void ratios, $i_{f 1}$ decreased with an increase in antecedent moisture content, whereas $i_{f 2}$ increased as antecedent moisture content increased through the dams. However, at high void ratios, under the same antecedent moisture contents, $i_{f 1}$ and $i_{f 2}$ increased with an increase in antecedent moisture content, suggesting seepage flow dynamics typical of laminar flows.

6. Furthermore, both $i_{f 1}$ and $i_{f 2}$ increased with an increase in $H_{d}$ and $D_{c r w}$, whereas $i_{f 1}$ increased with an increase in $\beta$, and $i_{f 2}$ decreased as $\beta$ increased. This indicates that the critical hydraulic gradient for dam failure for near-horizontal flow $\left(\Psi=5^{\circ}\right)$, depends on $\beta$.

7. These experiments demonstrate that seepage mechanisms in landslide dams comprised of unsaturated homogeneous and isotropic cohesionless materials are influenced by the hydraulic properties of the materials, as well as the geometrical characteristics of the dams.

8. The textural characteristics of the materials used in these experiments are typical of landslide dams formed by rock avalanche processes where fragmentation and pulverization of the rock materials cause seepage processes to develop in the upper blocky carapace layer.
9. However, further research should be done considering a wide range of sediment sizes and the addition of commercially available kaolinite clay to evaluate the mechanism of shear strength reduction under steady-state seepage. It is believed that performing unsaturated seepage analysis and limit equilibrium analysis, with regards to the results and conditions set for these experiments, could give further insights into the critical conditions for stability of landslide dams under steadystate seepage.

\section{Notation}

$C_{c}=$ coefficient of curvature

$C_{u}=$ coefficient of uniformity

$D_{c r w}(\mathrm{~m})=$ dam crest width

$D_{50}(\mathrm{~mm})=$ median grain size

$e_{o}=$ initial void ratio

$F_{s}\left(\mathrm{kN} / \mathrm{m}^{3}\right)=$ seepage force per unit volume

$H_{d}(\mathrm{~m})=$ height of the dam

$i_{1}=$ hydraulic gradient (between sensors $p 1$ and $p 2$ )

$i_{2}=$ hydraulic gradient (between sensors $p 2$ and $p 3$ )

$i_{\text {ini-1 }}=$ critical hydraulic gradient for seepage erosion initiation (between sensors $p 1$ and $p 2$ )

$i_{\text {ini-2 }}=$ critical hydraulic gradient for seepage erosion initiation (between sensors $p 2$ and $p 3$ )

$i_{f 1}=$ critical hydraulic gradient for collapse of the dam crest (between sensors $p 1$ and $p 2$ )

$i_{f 2}=$ critical hydraulic gradient for collapse of the dam crest (between sensors $p 2$ and $p 3$ )

$K(\mathrm{~m} / \mathrm{s})=$ coefficient of permeability

$p_{\text {crit-1 }}(\mathrm{kPa})=$ critical pore-water pressure for collapse of the dam crest at $p 1$

$p_{\text {crit-2 }}(\mathrm{kPa})=$ critical pore-water pressure for collapse of the dam crest at $p 2$

$p_{\text {crit-3 }}(\mathrm{kPa})=$ critical pore-water pressure for collapse of the dam crest at $p 3$

$Q_{\text {in }}\left(\mathrm{m}^{3} / \mathrm{s}\right)=$ inflow rate into the upstream reservoir

$T_{b}(\mathrm{~s})=$ time of collapse of the dam crest

$u_{w}(\mathrm{kPa})=$ pore-water pressure

$V_{\text {crit-1 }}(\mathrm{m} / \mathrm{s})=$ critical seepage velocity determined at $p 1$

$V_{\text {crit-2 }}(\mathrm{m} / \mathrm{s})=$ critical seepage velocity determined at $p 2$

$w(\%)=$ antecedent moisture content

$\alpha$ (degree $)=$ upstream slope angle

$\beta$ (degree $)=$ downstream slope angle

$\gamma^{\prime}\left(\mathrm{kN} / \mathrm{m}^{3}\right)=$ submerged unit weight of soil

$w\left(\mathrm{kN} / \mathrm{m}^{3}\right)=$ unit weight of water

$\lambda=$ seepage direction

$\rho_{\text {dry }}\left(\mathrm{Mg} / \mathrm{m}^{3}\right)=$ dry bulk density

$\phi($ degree $)=$ internal friction angle

$\psi($ degree $)=$ flume bed slope angle 


\section{Appendix 1}
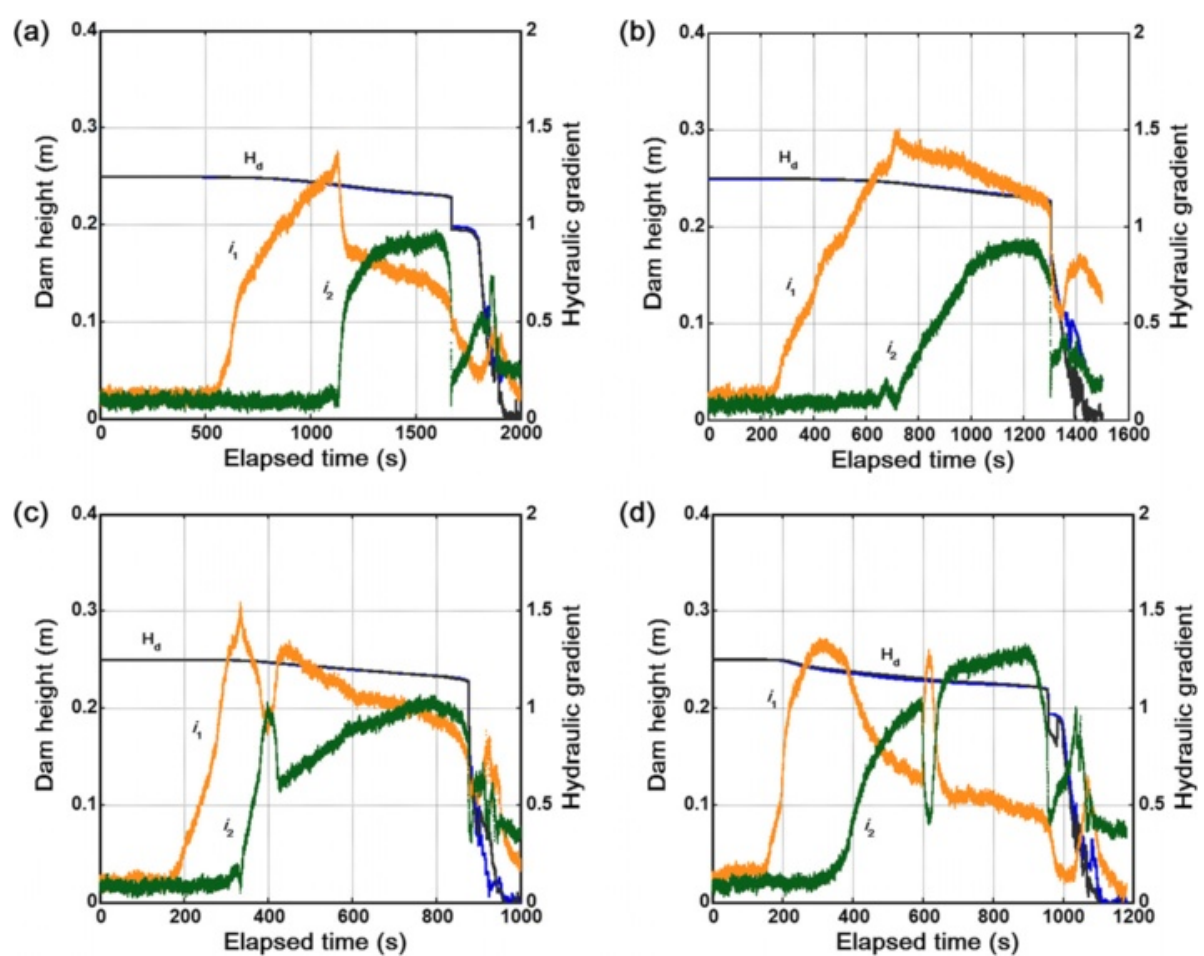

Fig. 13 Trends of hydraulic gradients in experiments carried out with upstream inflow rates of (a) $1.67 \times 10^{-5} \mathrm{~m}^{3} / \mathrm{s}$ (b) $5 \times 10^{-5} \mathrm{~m}^{3} / \mathrm{s}(\mathbf{c}) 1 \times 10^{-4}$ $\mathrm{m}^{3} / \mathrm{s}$ (d) $1.67 \times 10^{-4} \mathrm{~m}^{3} / \mathrm{s}$ 

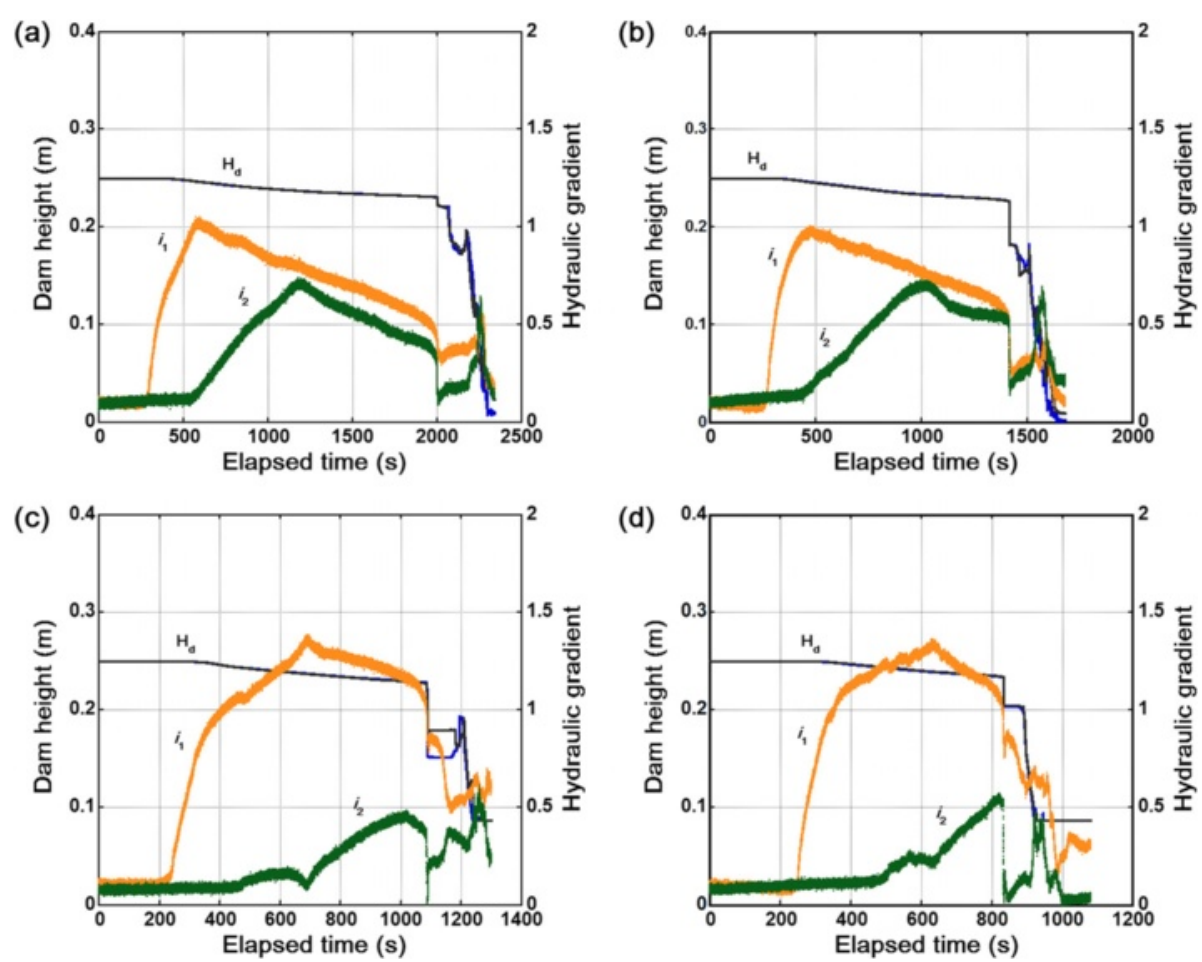

Fig. 14 Trends of hydraulic gradients in dams built with downstream slope angles of (a) $30^{\circ}$ (b) $40^{\circ}$ (c) $50^{\circ}$ (d) $60^{\circ}$

(a)

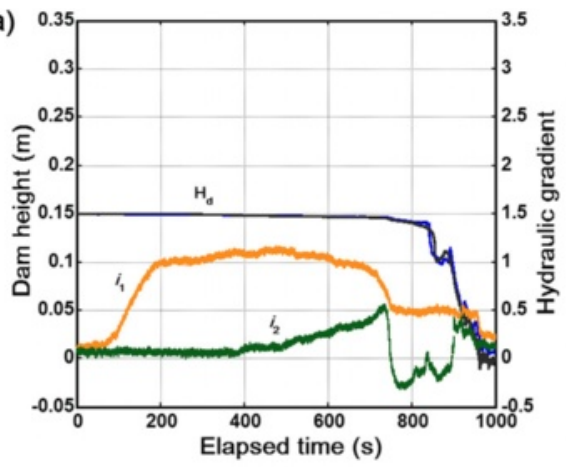

(c)

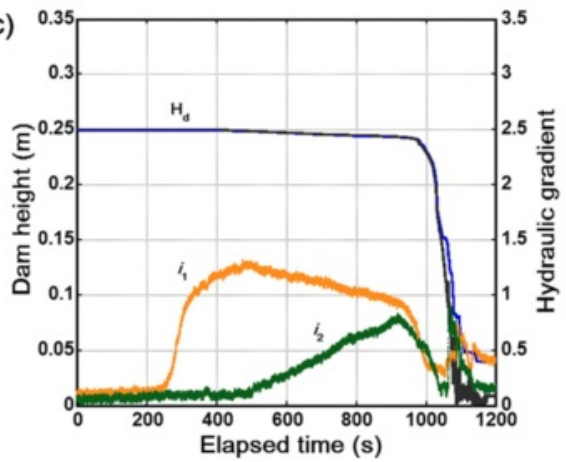

(b)

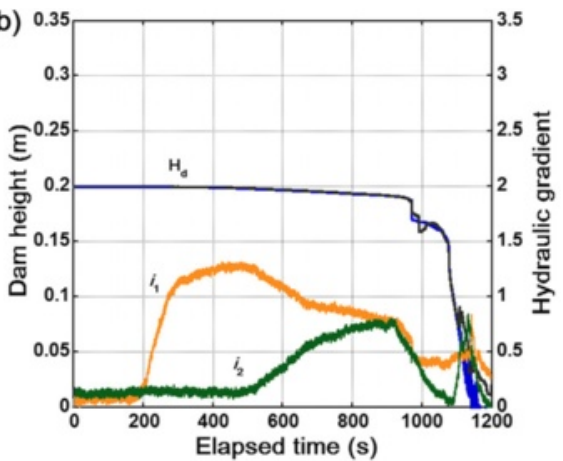

(d)

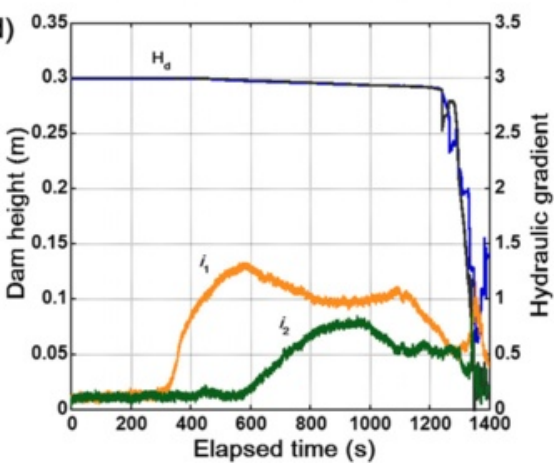

Fig. 15 Trends of hydraulic gradients in dams built with dam heights of (a) 0.15 m (b) $0.20 \mathrm{~m}$ (c) $0.25 \mathrm{~m}$ (d) $0.30 \mathrm{~m}$ 


\section{Appendix 2}
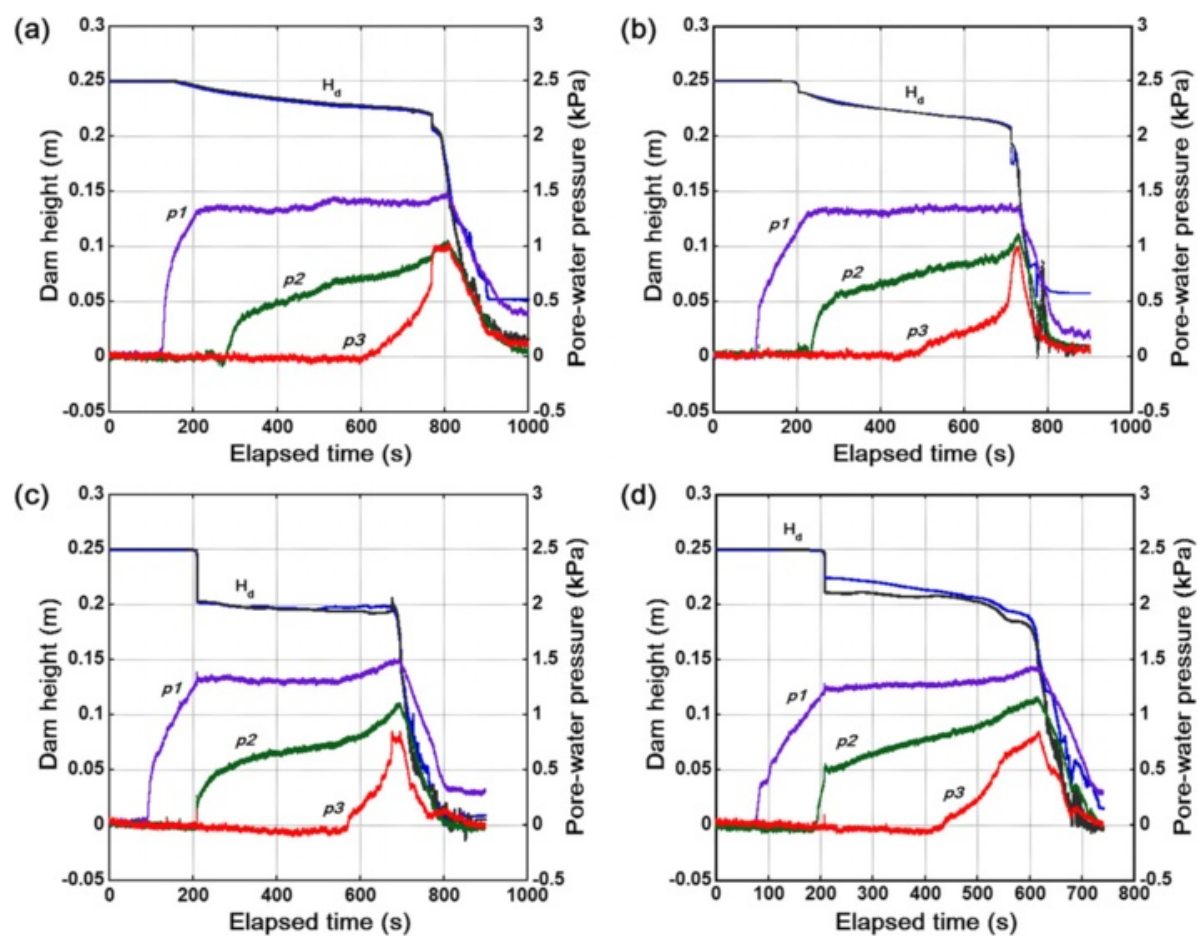

Fig. 16 Evolution of pore-water pressures in dams built with an $e_{0}$ of 1.76 and antecedent moisture contents of (a) $5 \%$ (b) $10 \%$ (c) $15 \%$ (d) $20 \%$

(a)

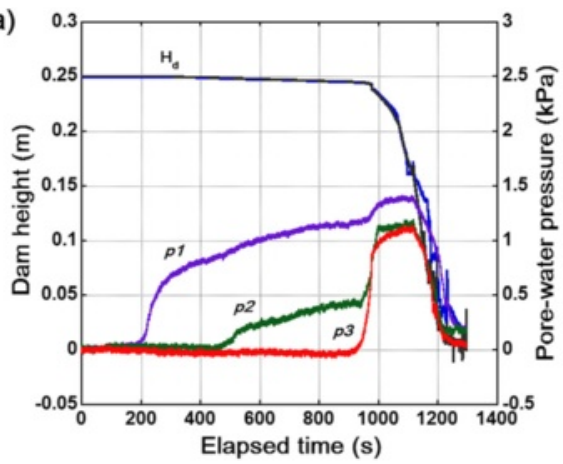

(c)

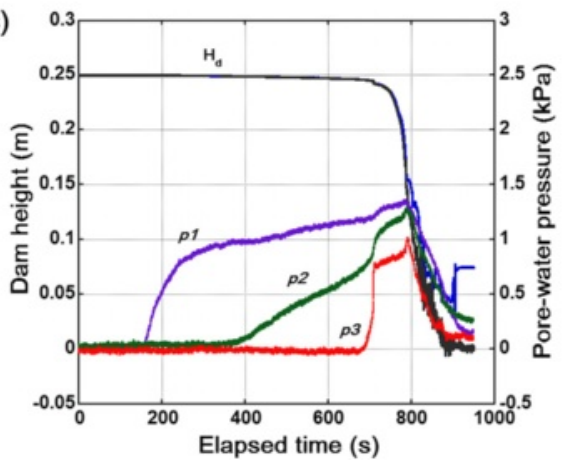

(b)

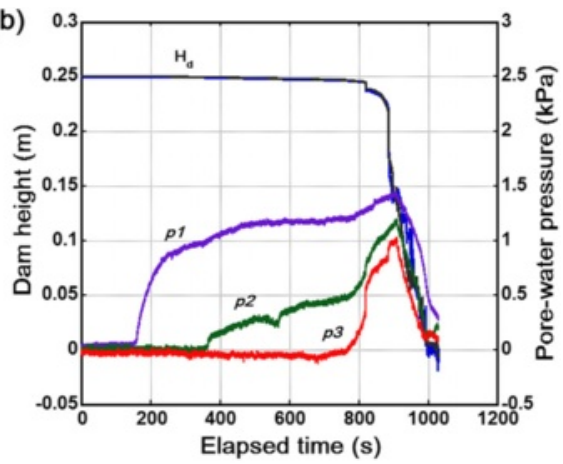

(d)

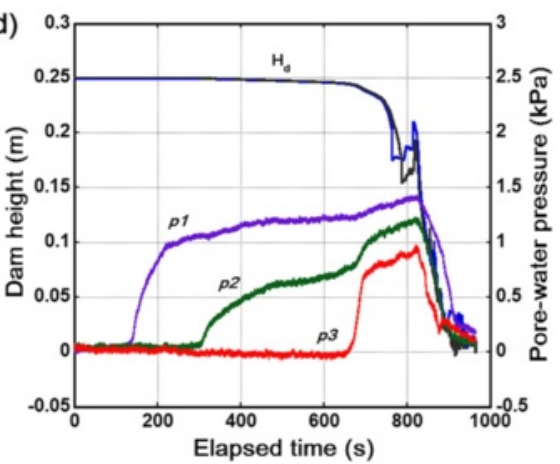

Fig. 17 Evolution of pore-water pressures in dams built with an $e_{0}$ of 1.21 and antecedent moisture contents of (a) $5 \%$ (b) $10 \%$ (c) $15 \%$ (d) $20 \%$ 

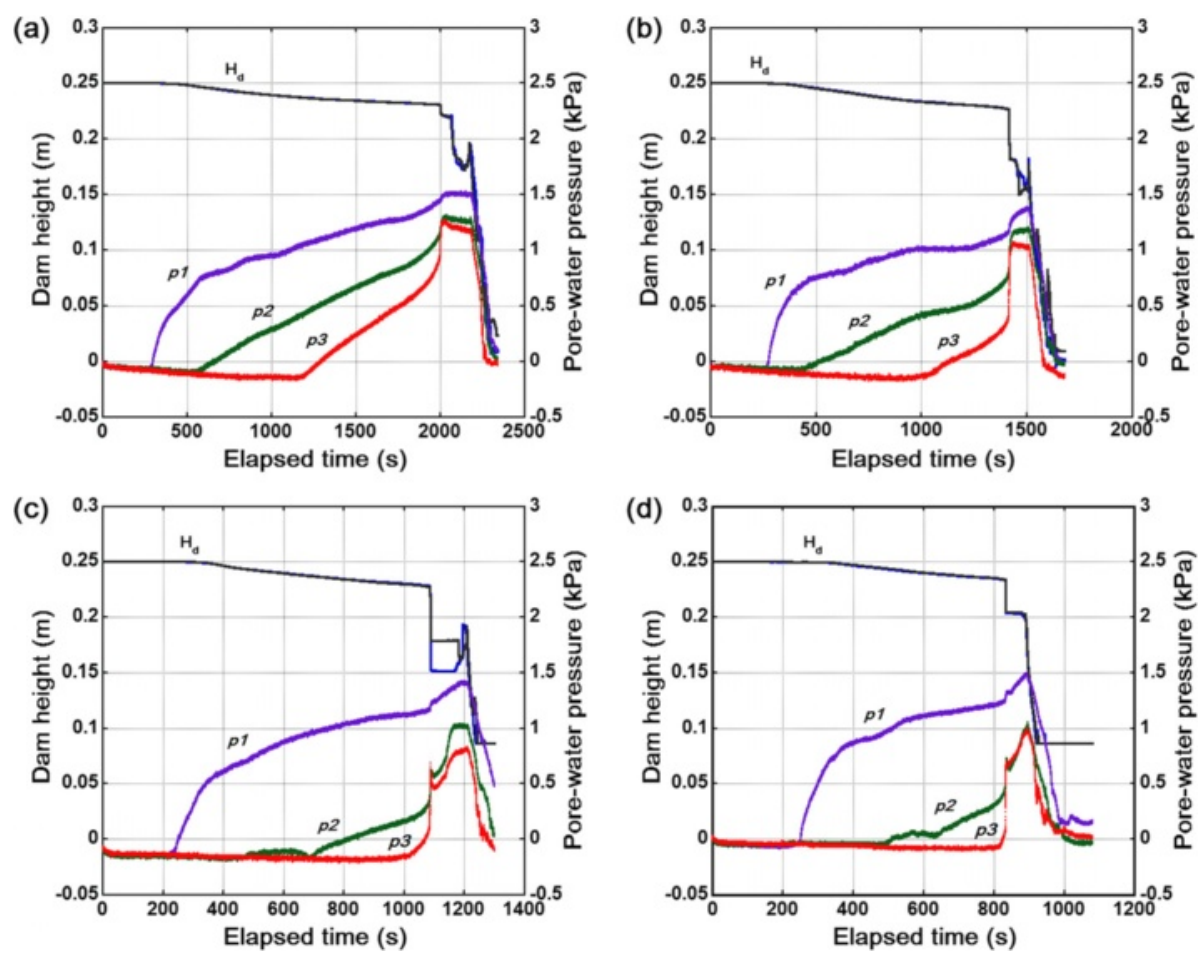

Fig. 18 Variations in pore-water pressures in dams built with downstream slope angles of (a) $30^{\circ}$ (b) $40^{\circ}$ (c) $50^{\circ}$ (d) $60^{\circ}$
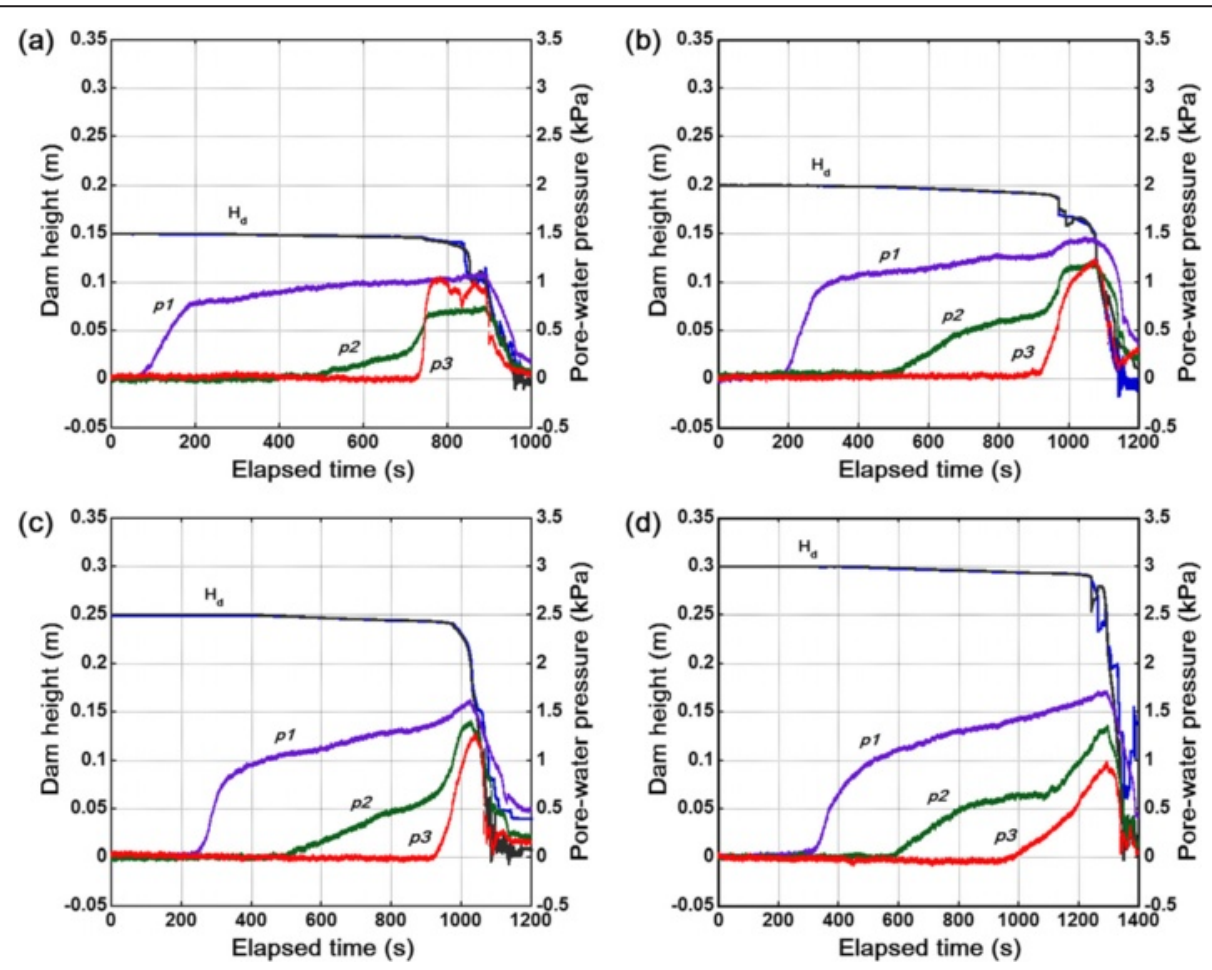

Fig. 19 Transient changes in pore-water pressures in dams built with dam heights of (a) 0.15 m (b) 0.20 m (c) $0.25 \mathrm{~m}$ (d) $0.30 \mathrm{~m}$ 


\section{Additional file}

Additional file 1: Video S1. Failure mechanism of Sandfill Dam (Experiment 1). (MP4 187388 kb)

\section{Competing interest}

The authors declare that they have no competing interests.

\section{Authors' contributions}

FW acquired the laboratory materials used in the research. ACO designed and conducted the experiments. FW supervised the research and made suggestions on the initial method adopted for the experiments. ACO analyzed the experimental results and wrote the first draft of the manuscript. All authors read and approved the final manuscript.

\section{Acknowledgements}

This investigation was financially supported by JSPS KAKENHI Grant Number A-2424106 for landslide dam failure prediction. Dr Solomon Obialo Onwuka (University of Nigeria, Nsukka) is gratefully acknowledged for his valuable comments and suggestions. The authors would like to thank the anonymous reviewers for reviewing the draft version of the manuscript.

\section{Received: 10 December 2015 Accepted: 4 May 2016}

\section{Published online: 18 May 2016}

\section{References}

Ahlinhan, M.F, and M. Achmus. 2010. Experimental investigation of critical hydraulic gradients for unstable soils. In Proceedings of the Fifth International Conference on Scour and Erosion, San Francisco, California, ed. S.E. Burns, S.K. Bhatia, C.M.C. Avila, and B.E. Hunt, 599-608. doi:10.1061/41147(392)58.

Allen, S.K., S.C. Cox, and I.F. Owens. 2011. Rock avalanches and other landslides in the central Southern Alps of New Zealand: a regional study considering possible climate change impacts. Landslides 8(1): 33-48.

Bligh, W.G. 1910. Dams, barrages and weirs on porous foundations. Engineering News 64(26): 708-710

Bonnard, C. 2011. Technical and human aspects of historic rockslide-dammed lakes and landslide dam breaches. In Natural and artificial rockslide dams, ed. S.G. Evans, R.L. Hermanns, A. Strom, and G. Scarascia-Mugnozza, 101-122. Berlin Heidelberg: Springer.

Bryan, R.B., and A. Yair. 1982. Badland Geomorphology and Piping, 408 Norwich: Geobooks.

Budhu, M., and R. Gobin. 1996. Slope instability from ground-water seepage. Journal of hydraulic Engineering 122(7):415-417.

Cancienne, R.M., G.A. Fox, and A. Simon. 2008. Influence of seepage undercutting on the stability of root-reinforced streambanks. Earth Surface Processes and Landforms 33(11): 1769-1786.

Cedergren, H.R. 1977. Seepage, drainage, and flow nets (Vol. 16), 1-534. New York: Wiley.

Chai, H.J., H.C. Liu, Z.Y. Zhang, and Z.W. Xu. 2000. The distribution, causes and effects of damming landslides in China. Journal of Chengdu University of Technology 27: 302-307.

Chang, D.S., and L.M. Zhang. 2012. Critical hydraulic gradients of internal erosion under complex stress states. Journal of Geotechnical and Geoenvironmental Engineering 139(9): 1454-1467.

Chugaev, R.R. 1962. Gründungsumriss von Wasserbauwerken (in Russian). Moskau - Leningrad

Clague, J.J., and S.G. Evans. 1994. Formation and failure of natural dams in the Canadian Cordillera, Geological Survey of Canada Bulletin, 464.

Costa, J.E., and R.L. Schuster. 1988. The formation and failure of natural dams. Geological Society of America Bulletin 100(7): 1054-1068.

Crosta, G., and C.D. Prisco. 1999. On slope instability induced by seepage erosion. Canadian Geotechnical Journal 36(6): 1056-1073.

Crosta, G.B., P. Frattini, and F. Agliardi. 2013. Deep seated gravitational slope deformations in the European Alps. Tectonophysics 605: 13-33.

Dai, F.C., C.F. Lee, J.H. Deng, and L.G. Tham. 2005. The 1786 earthquake-triggered landslide dam and subsequent dam-break flood on the Dadu River, southwestern China. Geomorphology 65(3): 205-221.

Dapporto, S., M. Rinaldi, and N. Casagli. 2001. Failure mechanisms and pore water pressure conditions: analysis of a riverbank along the Arno River (Central Italy). Engineering Geology 61(4): 221-242.

Darcy, H. 1856. Histoire des Foundataines Publique de Dijon, 590-594. Paris: Dalmont.
Davies, T.R., and M.J. McSaveney. 2011. Rock-avalanche size and runoutimplications for landslide dams. In Natural and Artificial Rockslide Dams, ed. S. G. Evans, R.L. Hermanns, A. Strom, and G. Scarascia-Mugnozza, 441-462. Berlin Heidelberg: Springer.

Den Adel, H., KJ. Bakker, and M. Klein Breteler. 1988. Internal Stability of Minestone. In Proceedings of the International Symposium on Modelling Soil-Water-Structure Interaction, International Association for Hydraulic Research (IAHR), Netherlands, ed. P. A. Kolkman, J. Lindenberg, and K.W. Pilarczyk, 225-231. Rotterdam: Balkema.

Dunne, T. 1990. Hydrology, mechanics, and geomorphic implications of erosion by subsurface flow. In Groundwater Geomorphology: The Role of Subsurface Water in Earth-Surface Processes and Landforms, Geol. Soc. Am. Spec. Pap. 252, ed. C.G. Higgins and D.R. Coates, 1-28.

Evans, S.G., K.B. Delaney, R.L. Hermanns, A. Strom, and G. Scarascia-Mugnozza. 2011. The formation and behaviour of natural and artificial rockslide dams; implications for engineering performance and hazard management. In Natural and artificial rockslide dams, ed. S.G. Evans, R.L. Hermanns, A. Strom, and G. Scarascia-Mugnozza, 1-75. Berlin Heidelberg: Springer.

Fell, R., and J.J. Fry. 2013. State of the art on the likelihood of internal erosion of dams and levees by means of testing. In Erosion in Geomechanics Applied to Dams and Levees, Chapter 1, ed. S. Bonelli, 1-99. London: ISTE-Wiley.

Fox, G.A., and G.V. Wilson. 2010. The role of subsurface flow in hillslope and stream bank erosion: a review. Soil Science Society of America Journal 74(3): 717-733.

Fox, G.A., G.V. Wilson, A. Simon, E.J. Langendoen, O. Akay, and J.W. Fuchs. 2007. Measuring streambank erosion due to groundwater seepage: correlation to bank pore water pressure, precipitation and stream stage. Earth Surface Processes and Landforms 32(10): 1558-1573.

Fredlund, D.G. 1995. The stability of slopes with negative pore-water pressures. In The lan Boyd Donald Symposium on Modern Developments in Geomechanics, vol. 3168, ed. C.M. Haberfield, 99-116. Clayton: Monash University, Department of Civil Engineering.

Fredlund, D.G. 1999. The scope of unsaturated soil mechanics: an overview. In The Emergence of Unsaturated Soil Mechanics: Fredlund Volume, ed. A. W. Clifton, G.W. Wilson, and S.L. Barbour, 140-156. Ottawa: NRC Research Press.

Fredlund, D.G., N.R. Morgenstern, and R.A. Widger. 1978. The shear strength of unsaturated soils. Canadian Geotechnical Journal 15(3): 313-321.

Fredlund, D.G., H. Rahardjo. 1993. Soil mechanics for unsaturated soils. John Wiley \& Sons. New York.

Fredlund, D.G., H. Rahardjo, and M.D. Fredlund. 2012. Unsaturated soil mechanics in engineering practice, 926. New York: Wiley.

Ghiassian, H., and S. Ghareh. 2008. Stability of sandy slopes under seepage conditions. Landslides 5(4): 397-406.

Hagerty, D.J. 1991. Piping/sapping erosion: 1 Basic considerations. Journal of Hydraulic Engineering 117: 991-1008.

Higgins, C.G. 1982. Drainage systems developed by sapping on Earth and Mars. Geology 10(3): 147-152.

Higgins, C.G. 1984. Piping and sapping; development of landforms by groundwater outflow, 18-58. Boston: Allen \& Unwin.

Howard, A.D. 1988. Groundwater sapping experiments and modeling. Sapping Features of the Colorado Plateau: A Comparative Planetary Geology Field Guide 491: 71-83.

Howard, A.D., and C.F. McLane. 1988. Erosion of cohesionless sediment by groundwater seepage. Water Resources Research 24(10): 1659-1674.

Hutchinson, J.N. 1982. Damage to slopes produced by seepage erosion in sands. In Landslides and mudflows, 250-265. Moscow: Centre of International Projects, GKNT.

Iverson, R.M., and J.J. Major. 1986. Groundwater seepage vectors and the potential for hillslope failure and debris flow mobilization. Water Resources Research 22(11): 1543-1548.

Jones, J.A.A. 1981. The nature of soil piping: A review of research. In Brit. Geomorphol. Res. Group Res. Monogr. Serie 3. Norwich: Geobooks.

Ke, L., and A. Takahashi. 2012. Influence of internal erosion on deformation and strength of gap-graded non-cohesive soil. In Proceedings of the Sixth International Conference on Scour and Erosion, Paris, 847-854.

Kokusho, T., and Y. Fujikura. 2008. Effect of particle gradation on seepage failure in granular soils. In 4th Int'l Conf. on Scour and Erosion, Tokyo, Japan, 497-504

Korup, O., and F. Tweed. 2007. Ice, moraine, and landslide dams in mountainous terrain. Quaternary Science Reviews 26(25): 3406-3422.

Korup, O. A.L. Densmore, and F. Schlunegger. 2010. The role of landslides in mountain range evolution. Geomorphology 120(1): 77-90. 
Lam, L., D.G. Fredlund, and S.L. Barbour. 1987. Transient seepage model for saturated-unsaturated soil systems: a geotechnical engineering approach. Canadian Geotechnical Journal 24(4): 565-580.

Lane, E.W. 1935. Security from under-seepage masonry dams on earth foundations. Transactions of the American Society of Agricultural Engineers 60(4): 929-966.

Lobkovsky, A.E., B. Jensen, A. Kudrolli, and D.H. Rothman. 2004. Threshold phenomena in erosion driven by subsurface flow. Journal of Geophysical Research 109: F04010. doi:10.1029/2004JF000172.

Meyer, W., R.L. Schuster, and M.A. Sabol. 1994. Potential for seepage erosion of landslide dam. Journal of Geotechnical Engineering 120(7): 1211-1229.

Moffat, R., R.J. Fannin, and S.J. Garner. 2011. Spatial and temporal progression of internal erosion in cohesionless soil. Canadian Geotechnical Journal 48(3): 399-412.

Müller-Kirchenbauer, H., M. Rankl, and C. Schlötzer. 1993. Mechanism for regressive erosion beneath dams and barrages. In Proceedings of the First International Conference on Filters in Geotechnical and Hydraulic Engineering, ed. J. Brauns, M. Heibaum, and U. Schuler, 369-376. Rotterdam: Balkema.

O'Connor, J.E., and J.E. Costa. 2004. The world's largest floods, past and present: their causes and magnitudes. In U.S Geological Survey Circular, 1254, 13.

Okamura, M., and Y. Soga. 2006. Effects of pore fluid compressibility on liquefaction resistance of partially saturated sand. Soils and Foundations 46(5): 695-700.

Okeke, A.C.U., and F. Wang. 2016. Hydromechanical constraints on piping failure of landslide dams: an experimental investigation. Geoenvironmental Disasters $3(1): 1-17$.

Pagano, L., E. Fontanella, S. Sica, and A. Desideri. 2010. Pore water pressure measurements in the interpretation of the hydraulic behaviour of two earth dams. Soils and Foundations 50(2): 295-307.

Perzlmaier, S., P. Muckenthaler, and A.R. Koelewijn. 2007. Hydraulic criteria for internal erosion in cohesionless soil. Assessment of risk of internal erosion of water retaining structures: dams, dykes and levees. In Intermediate Report of the European Working Group of ICOLD, 30-44. Munich: Technical University of Munich.

Plaza, G., O. Zevallos, and É. Cadier. 2011. La Josefina Landslide Dam and Its Catastrophic Breaching in the Andean Region of Ecuador. In Natural and artificial rockslide dams, ed. S.G. Evans, R.L. Hermanns, A. Strom, and G. Scarascia-Mugnozza, 389-406. Berlin Heidelberg: Springer.

Richards, K.S., and K.R. Reddy. 2007. Critical appraisal of piping phenomena in earth dams. Bulletin of Engineering Geology and the Environment 66(4): 381-402.

Richards, K.S., and K.R. Reddy. 2010. True triaxial piping test apparatus for evaluation of piping potential in earth structures. Journal of ASTM Geotech Test 33(1): 83-95.

Rinaldi, M., and N. Casagli. 1999. Stability of streambanks formed in partially saturated soils and effects of negative pore water pressures: the Sieve River (Italy). Geomorphology 26(4): 253-277.

Samani, Z.A., and L.S. Willardson. 1981. Soil hydraulic stability in a subsurface drainage system. Transactions of the American Society of Agricultural Engineers 24(3): 666-669.

Simon, A., and A.J. Collison. 2001. Pore-water pressure effects on the detachment of cohesive streambeds: seepage forces and matric suction. Earth Surface Processes and Landforms 26(13): 1421-1442.

Skempton, A.W., and J.M. Brogan. 1994. Experiments on piping in sandy gravels. Geotechnique 44(3): 449-460.

Terzaghi, K. 1943. Theoretical soil mechanics, 1-510. New York: Wiley.

Terzaghi, K., R.B. Peck, and G. Mesri. 1996. Soil Mechanics in Engineering Practice, 3rd ed. New York: Wiley.

Wan, C.F., and R. Fell. 2004. Experimental investigation of internal instability of soils in embankment dams and their foundations, NICIV Report No. R429. Sydney: University of South Wales.

Wang, G., R. Huang, T. Kamai, and F. Zhang. 2013. The internal structure of a rockslide dam induced by the 2008 Wenchuan ( $M$ w 7.9) earthquake, China. Engineering Geology 156:28-36.

Wang, F.W., Y. Kuwada, A.C. Okeke, M. Hoshimoto, T. Kogure, and T. Sakai. in press. Comprehensive study on failure prediction of landslide dams by piping. 12th Proc. International Symposium on Landslides, Napoli, Italy.

Weijers, J.B.A., and J.B. Sellmeijer. 1993. A new model to deal with the piping mechanism. In Proceedings of the First International Conference on Filters in Geotechnical and Hydraulic Engineering, ed. J. Brauns, M. Heibaum, and U. Schuler, 345-355. Rotterdam: Balkema.
Wilson, G.V., R.K. Periketi, G.A. Fox, S.M. Dabney, F.D. Shields, and R.F. Cullum. 2007. Soil properties controlling seepage erosion contributions to streambank failure. Earth Surface Processes and Landforms 32(3): 447-459.

Wörman, A. 1993. Seepage-induced mass wasting in coarse soil slopes. Journal of Hydraulic Engineering 119(10): 1155-1168.

Zasłavsky, D., and G. Kassiff. 1965. Theoretical formulation of piping mechanism in cohesive soils. Geotechnique 15(3): 305-316.

\section{Submit your manuscript to a SpringerOpen ${ }^{\circ}$ journal and benefit from:}

- Convenient online submission

- Rigorous peer review

- Immediate publication on acceptance

- Open access: articles freely available online

- High visibility within the field

- Retaining the copyright to your article

Submit your next manuscript at springeropen.com 